Article

\title{
Soybean (Glycine max) Protein Hydrolysates as Sources of Peptide Bitter-Tasting Indicators: An Analysis Based on Hybrid and Fragmentomic Approaches
}

\author{
Anna Iwaniak ${ }^{*}+\left(\mathbb{D}\right.$, Monika Hrynkiewicz ${ }^{\dagger}$, Piotr Minkiewicz ${ }^{\mathbb{D}}$, Justyna Bucholska and \\ Małgorzata Darewicz *iD \\ Faculty of Food Science, University of Warmia and Mazury in Olsztyn, Chair of Food Biochemistry, \\ Pl. Cieszyński 1, 10-719 Olsztyn-Kortowo, Poland; monika.protasiewicz@uwm.edu.pl (M.H.); \\ minkiew@uwm.edu.pl (P.M.); justyna.bucholska@uwm.edu.pl (J.B.) \\ * Correspondence: ami@uwm.edu.pl (A.I.); darewicz@uwm.edu.pl (M.D.); Tel.: +48-89-523-3722 (A.I.) \\ + These authors equally contributed to this work.
}

Received: 2 March 2020; Accepted: 3 April 2020; Published: 6 April 2020

check for updates

\begin{abstract}
The aim of this study was to analyze soybean proteins as sources of peptides likely to be bitter using fragmentomic and hybrid approaches involving in silico and in vitro studies. The bitterness of peptides (called parent peptides) was theoretically estimated based on the presence of bitter-tasting motifs, particularly those defined as bitter-tasting indicators. They were selected based on previously published multilinear stepwise regression results. Bioinformatic-assisted analyses covered the hydrolysis of five major soybean-originating protein sequences using bromelain, ficin, papain, and proteinase K. Verification of the results in experimental conditions included soy protein concentrate (SPC) hydrolysis, RP-HPLC (for monitoring the proteolysis), and identification of peptides using RP-HPLC-MS/MS. Discrepancies between in silico and in vitro results were observed when identifying parent peptide SPC hydrolysate samples. However, both analyses revealed that conglycinins were the most abundant sources of parent peptides likely to taste bitter. The compatibility percentage of the in silico and in vitro results was 3\%. Nine parent peptides with the following sequences were identified in SPC hydrolysates: LSVISPK, DVLVIPLG, LIVILNG, NPFLFG, ISSTIV, PQMIIV, PFPSIL, DDFFL, and FFEITPEK (indicators are in bold). The fragmentomic idea of research might provide a supportive method for predicting the bitterness of hydrolysates. However, this statement needs to be confirmed experimentally.
\end{abstract}

Keywords: bioinformatics; BIOPEP-UWM database; bitter-tasting peptides; hydrolysates; soybean proteins

\section{Introduction}

Soybean has been known as a food for thousands of years [1] and recently has become increasingly popular among consumers for ecological, ethical, and health-beneficial concerns [2]. Its health-beneficial properties are due to the presence of biologically active components like isoflavones, saponins, protease inhibitors, and peptides. Briefly, their activity is related to their preventive potential against cardiovascular disease, diabetes, menopausal symptoms, osteoporosis, prostate, and breast cancers. According to the literature, peptides derived from soybean proteins are responsible for a variety of activities that regulate body functions, e.g., reduction of blood pressure, cholesterol, and carbohydrate levels, as well as exhibit anti-inflammatory, antioxidative, and anticancer effects. The first three "reducing" functions of peptides are related to the inhibition of the following enzymes: ACE (angiotensin converting enzyme, EC 3.4.15.1), 
DPP IV (dipeptidyl peptidase IV; EC 3.4.14.5), and HMGR (3-hydroxy-3-methylglutaryl-coenzyme A reductase; EC 1.1.1.34), respectively [1].

Quite often, the biological function of a peptide is associated with bitter taste; thus, both peptides and protein hydrolysates may not be acceptable by consumers due to the undesired taste profile [3]. Due to the fact that peptides are derived from food proteins, they are considered as "natural". Thus, their sensory acceptance poses a challenge for food scientists and technologists who aim at producing functional foods [3], especially when some of the bioactive peptides negatively affect the taste of a protein hydrolysate [4].

Currently, three approaches are used to study peptides from foods [5]. The first one is called a classical approach, and briefly, it is an experimental protocol consisting of the main methodological steps like hydrolysis of protein, identification of peptides, and determination of the bioactivity of the hydrolysate(s), as well as the peptide(s). The other two approaches benefit from the progress in the development and application of bioinformatics and chemometrics in the food science. This results from the increasing popularity of databases of biomolecules as sources of information about, e.g., peptides, as well as programs serving for peptide analyses. Thus, the method for studying peptides involving the application of bioinformatic and/or cheminformatic predictions is called an in silico approach, whereas the combination of the classical and in silico protocols is defined as a hybrid approach [5].

Some in silico studies were undertaken to analyze the impact of the amino acid composition of peptides on their bitterness. For example, the bitterness of peptides was found to result from the presence of residues with bulky and branched side chains, like Leu, Ile, Tyr, Phe, and Val. According to the literature, the first three of these amino acids were found to be extremely bitter with an unpleasant flavor and odor [6].

The fact that some regularities can be observed between the presence of the specific amino acid(s) and the function of a whole peptide sequence has prompted some scientists to find the foundations for introducing the fragmentomic idea of research. According to this idea, shorter motifs (fragments) with a known property encrypted in a molecule of interest may affect its function [7]. According to Liu et al. [8], motifs are generally understood as reproducible patterns in a protein or peptide sequence that are ascribed to a specific biological function (in this case, taste). This applies also to peptides identified in a food protein hydrolysate. For example, a sequence identified (i.e., precursor/parent peptide) that contains peptide motifs with confirmed bitterness (i.e., bitter-tasting motifs) may suggest the bitter-tasting potential of a parent sequence. Such an idea of research was applied by Iwaniak et al. [9] for the hybrid analysis of bovine milk protein hydrolysates as sources of bitter-tasting motifs, especially those with an "indicator" status.

To sum up, soybean protein hydrolysates are known sources of bioactive peptides. According to the literature, soybean hydrolysates taste bitter, which may be due to the presence of peptide sequences [10]. Taking into account these two facts, the aim of this study was to apply the hybrid protocol for an analysis of soybean protein hydrolysates as sources of peptides likely to be bitter due to the presence of bitter-tasting motifs, particularly those defined as bitter-tasting indicators. According to the definition introduced by Iwaniak et al. [9], bitter-tasting indicators should be literally understood as "shorter motifs with known bitterness, which found in the sequences of peptides, may potentially determine their taste".

\section{Materials and Methods}

\subsection{Soybean Protein Sequences and Computer Simulation of Their Hydrolysis}

Five sequences of soybean (Glycine max) proteins, namely: 7S globulin (403 aa, P13917), glycinin (492 aa, P04347), $\beta$-chain of $\beta$-conglycinin, (414 aa, P25974), $\alpha$-chain of $\beta$-conglycinin (543 aa, P13916), and profilin (130 aa, O65809), were acquired from the UniProt database [11] (accessed December 2018). The number of amino acids in a protein chain, as well as the accession number of proteins in UniProt are provided in brackets. 
The BIOPEP-UWM database [12] tool called "Enzyme(s) action" was applied for computer simulation of hydrolysis. Each soybean protein sequence was theoretically hydrolyzed by bromelain, ficin, papain, and proteinase $K$, respectively. The following steps were required to hydrolyze protein when opening the BIOPEP-UWM tool: Sensory peptides and amino acids $\rightarrow$ Analysis $\rightarrow$ Enzyme(s) action $\rightarrow$ For your sequence $\rightarrow$ Paste the protein sequence (e.g., 7S globulin) $\rightarrow$ Select the enzyme (e.g., bromelain) $\rightarrow$ View the report with the results. Motifs that were theoretically released from a protein, excluding single amino acids, were copied, and each of them was searched for the presence of bitter-tasting peptides, according to the following protocol: BIOPEP-UWM sensory peptides and amino acids $\rightarrow$ Analysis $\rightarrow$ Profiles of proteins potential sensory activity $\rightarrow$ For your sequence $\rightarrow$ Paste the released peptide (e. g., VFDG) $\rightarrow$ Report. Bitter-tasting indicators (see below) were searched manually after making the above-mentioned analysis. Moreover, the potentially released peptide was searched for showing an additional bioactivity (if any) using an analogical procedure, by selecting "Bioactive peptides" instead of the "Sensory peptides and amino acids" tab after opening the BIOPEP-UWM database.

\subsection{Bitter-Tasting Peptide Indicators}

Peptides possessing a status of bitter-tasting indicators were selected from the BIOPEP-UWM database collection of 102 bitter di- and tri-peptides (51 sequences of di- and tri-peptides each) that were analyzed using multivariate linear stepwise regression (MLR) [13]. Based on the MLR results, those peptides whose experimental measures of bitterness were approximative to the theoretical ones were defined as bitter-tasting peptidic indicators. They were as follows: $\operatorname{PK}(0.17 ; 0.08), \operatorname{AD}(0.17 ; 0.10)$, $\mathrm{VD}(0,08 ; 0.10), \operatorname{VE}(0.17 ; 0.15), \operatorname{EI}(0.25 ; 0.18), \mathrm{YG}(0.33 ; 0.27), \mathrm{VL}(0.17 ; 0.21), \mathrm{VI}(0.17 ; 0.21), \mathrm{LG}(0.05 ; 0.16)$, GV(0.22;0.25), GP(0.17;0.25), RG(0.13;0.21), IG(0.22;0.19), LE(0.33;0.32), KP(0.33;0.33), VF(0.33;0.37), $\operatorname{VY}(0.33 ; 0.37), \operatorname{LL}(0.4 ; 0.37), \operatorname{FI}(0.67 ; 0.56), \operatorname{IF}(0.67 ; 0.56), \operatorname{FL}(0.67 ; 0.60), \operatorname{FF}(0.83 ; 0.72), \operatorname{PGR}(0.04 ; 0.26)$, GGP(0.11;0.12), GGV(0.03;0.10), GLG(0.1;0.17), PPG(0.11;0.03), LGL(0.20;0.07), FGG(0.22;0.02), $\operatorname{VVV}(0.22 ; 0.05), \quad G G L(0.1 ; 0.12), \operatorname{GVV}(0.22 ; 0.17), \operatorname{PGP}(0.11 ; 0.25), \quad \operatorname{KPK}(0.33 ; 0.37), \quad Y G G(0.43 ; 0.52)$, $\operatorname{PGI}(0.43 ; 0.48), \quad \operatorname{PPP}(0.50 ; 0.66), \operatorname{GLL}(0.67 ; 0.69), \quad \operatorname{LLL}(0.83 ; 0.64), \operatorname{GGF}(0.67 ; 0.76), \operatorname{GGY}(0.67 ; 0.74)$, $\operatorname{PIP}(0.70 ; 0.82)$, GYY $(2.50 ; 2.32)$. Finally, 21 dipeptides and 21 tripeptides achieved the status of a bitter taste indicator. Their experimental and theoretical bitterness are provided in the brackets, respectively. The experimental bitterness of a peptide was expressed as Rcaf. value, meaning the threshold concentration for $1 \mathrm{~mm}$ caffeine solution as a standard (the higher the Rcaf. value, the bitterer the peptide is) [14].

\subsection{Materials and Reagents}

Soy protein concentrate (SPC) called Isomil@(containing $68 \%$ protein, according to the product specification) was produced by Libra Poland Ltd. (Warsaw, Poland). Enzymes: bromelain (EC 3.4.22.32; 5-15 units/mg protein; Cat. No. B5144), ficin (EC 3.4.22.3, $\geq 1$ unit/mg protein; Cat. No. F4125), papain (EC 3.4.22.2, 10 units/mg protein; Cat. No. P4762), and proteinase K from Tritirachium album (EC 3.4.21.64, $\geq 30$ units/mg protein; Cat. No. P2308), and trifluoroacetic acid (TFA), acetonitrile (ACN), 2,2-bis(hydroxymethyl)-2,2' 2"'-nitrilotriethanol (Bis-Tris), 2-mercaptoethanol, and urea were purchased from Sigma-Aldrich Sp. z o.o. (Poznań, Poland). All chemicals were of analytical grade. Water used to formulate solutions and buffers was prepared using a Milli-Q PLUS system (Millipore Corp., New York, NY, USA).

\subsection{Hydrolysis of SPC}

SPC hydrolysis was carried out according to the protocol provided by Peñta-Ramos and Xiong [15] with slight modifications. Firstly, five separate water solutions of SPC containing $3 \%$ protein $(\mathrm{w} / \mathrm{v})$ each were prepared. All of them had the non-adjusted $\mathrm{pH}$ of $7.0 \pm 0.1$. SPC solutions were continuously and gently stirred, as well as pre-heated for 5 min using a Heidolph Unimax Modular Incubator 1010 (Heidolph Instruments GmbH \& CO. KG, Schwabach, Germany). The preincubation temperatures were 
typical of the activity of enzymes used, according to their specifications provided by the manufacturer, and were as follows: bromelain and ficin $\left(50^{\circ} \mathrm{C}\right)$, papain $\left(65^{\circ} \mathrm{C}\right)$, and proteinase $\mathrm{K}\left(37^{\circ} \mathrm{C}\right)$. Finally, 3 hour hydrolysis of four SPC samples was conducted under continuous stirring and the enzyme-to-substrate ratio (protein) of 1:100 $(\mathrm{w} / \mathrm{w})[15,16]$. The $\mathrm{pH}$ values of SPC solutions were optimal for enzyme activity as provided by the manufacturer, i.e.: 7.0 for bromelain, papain, and proteinase $\mathrm{K}$; and 6.5 for ficin. In the case of the last sample, its $\mathrm{pH}$ was adjusted using $0.1 \mathrm{M} \mathrm{HCl}$. Afterwards, all hydrolysates were heated at $90{ }^{\circ} \mathrm{C}$ for $15 \mathrm{~min}$ to inactivate the enzymes and then freeze-dried. Finally, four SPC hydrolysates were produced, namely B-SPC, F-SPC, P-SPC, and PK-SPC, the abbreviations referring to bromelain-, ficin-, papain-, and proteinase-K-SPC hydrolysates, respectively, according to the convention used in the previous paper [9]. The fifth sample, 0-SPC, was a reference sample being the non-hydrolyzed SPC solution. All hydrolysates were prepared in duplicate.

\subsection{RP-HPLC for Monitoring the Process of SPC Hydrolysis and RP-HPLC-MS/MS for the Identification of SPC-Originating Peptides}

RP-HPLC (reversed-phase high performance liquid chromatography) was applied to observe the progress in the hydrolysis of SPC using the above-mentioned enzymes. The preparation of SPC/SPC hydrolysate samples taken for RP-HPLC and RP-HPLC-MS/MS (reversed-phase high performance liquid chromatography online with tandem mass spectrometry), as well as the parameters of devices for chromatography were exactly the same as in the protocol by Iwaniak et al. [9].

Firstly, two milligrams of freeze-dried SPC/SPC hydrolysate sample were dissolved in $300 \mu \mathrm{L}$ of a buffer containing $0.1 \mathrm{M}$ Bis-Tris and $4 \mathrm{M}$ urea. Then, two microliters of 2-mercaptoethanol were added, and the mixture was vortexed and finally incubated at room temperature (1 hour). Then, six-hundred-eighty microliters of $6 \mathrm{M}$ urea solution in a mixture of $\mathrm{ACN}$ and $\mathrm{H}_{2} \mathrm{O}$ (v/v; 100: 900; $\mathrm{pH}$ 2.2 was adjusted by the addition of TFA) were added to the sample and stirred. Finally, the samples were centrifuged $(10 \mathrm{~min} ; 10,000 \times g)$ [9].

The RP-HPLC analysis was carried out on Shimadzu ${ }^{\circledR}$ devices comprised of two LC-20AD pumps, an SIL-20AC HT autosampler, a CBM-20A controller, a CTO-10AS VP thermostat, an SPD-M20A photodiode detector, a DGU-20A5 degasser, and an FRC-10A fraction collector. The Jupiter Proteo Phenomenex ${ }^{\circledR}$ column (Torrance, CA, USA; $250 \times 2 \mathrm{~mm}$; particle diameter: $4 \mu \mathrm{m}$; pore diameter: $90 \AA$ ) was applied for RP-HPLC analysis of the samples. According to the protocol by Iwaniak et al. [9], Solvent A was $0.01 \%$ TFA water solution (v/v), whereas Solvent B was $0.01 \%(v / v)$ TFA dissolved in acetonitrile (ACN). The gradient of Solvent B increased from 0 to $40 \%$ during $60 \mathrm{~min}$. The column was washed with Solvent B (40-100 \%, 60-65 min; 100\%, 65-70 min, $100-0 \%, 70-71 \mathrm{~min} ; 0$ \%, 71-80 min). Data registration was between the 0th and 80th minute of the RP-HPLC analysis. The injection volume was $30 \mu \mathrm{L}$; the flow rate was $0.2 \mathrm{~mL} \times \mathrm{min}^{-1}$; and the column temperature was $30^{\circ} \mathrm{C}$. All chromatograms were acquired at $220 \mathrm{~nm}$ [9]. Finally, the chromatographic profiles of the samples taken before the 60th min of the RP-HPLC analysis were the subject of discussion.

Similarly, the exact procedure as that described by Iwaniak et al. [9] was applied for the identification of peptides released from SPC hydrolysates using RP-HPLC-MS/MS. Briefly, the identification of peptides was carried out using the VARIAN ${ }^{\circledR}$ 500-MS (Agilent Technologies, Santa Clara, CA, USA) ion trap mass spectrometer with an electrospray ion source and an RP-HPLC assembly comprised of two 212-LC pumps, a ProStar 410 autosampler, a Degassit degasser (MetaChem Technologies ${ }^{\circledR}$, Torrance, CA, USA), and a nitrogen generator (Parker Domnick Hunter Scientific ${ }^{\circledR}$, Gateshead, U.K.). Data were registered between 5 and $60 \mathrm{~min}$. The other parameters for mass spectrometry included: needle and shield voltages: 5000 and $600 \mathrm{~V}$, respectively; spraying and drying gas (nitrogen) pressure: 55 and $30 \mathrm{psi}$, respectively; drying gas temperature: $390{ }^{\circ} \mathrm{C}$; flow rate of damping gas (helium): $0.8 \mathrm{~mL} \times \mathrm{min}^{-1}$; positive polarity with current ionization: $600 \mathrm{~V}$; capillary voltage: $100 \mathrm{~V}$; retardation factor loading: $100 \%$; isolation window: 3.0; excitation storage level $\mathrm{m} / \mathrm{z}=100-2000 \mathrm{Da}$; flow rate: $0.2 \mathrm{~mL} \times \mathrm{min}^{-1}$; injection volume: $15 \mu \mathrm{L}$; frequency of data recording: 0.05- $0.07 \mathrm{~Hz}$ single scan averaged from five microscans. The gradient and column type including its 
parameters were identical to those presented above [9]. Peptides were identified by comparison of experimental mass-to-charge ratios, and the ratios were calculated using the Fragment Ion Calculator program (http://db.systemsbiology.net:8080/proteomicsToolkit/FragIonServlet.html) as described in our previous article [9]. All analyses were performed in duplicate.

We introduced an additional parameter to compare the susceptibility of proteins to particular proteolytic enzymes:

$$
\mathrm{C}=\left(\mathrm{S}_{\text {shorter }}-\mathrm{S}_{0 \text { shorter }}\right) / \mathrm{S}_{\text {longer }}
$$

where:

$\mathrm{S}_{\text {shorter: }}$ relative area of peaks between 14.00 and $39.99 \mathrm{~min}$ in the chromatogram of the hydrolysate;

$\mathrm{S}_{0 \text { shorter: }}$ relative area of peaks between 14.00 and $39.99 \mathrm{~min}$ in the chromatogram of the non-hydrolyzed sample;

Slonger: relative area of peaks between 40.00 and $60.00 \mathrm{~min}$ in the chromatogram of the hydrolysate.

Retention time prediction is a helpful strategy supporting peptide identification by mass spectrometry [17]. To facilitate peptide identification, their theoretical retention times $\left(t_{R}\right.$ predicted $)$ were calculated and then compared with the experimental $\left(t_{R}\right.$ experimental $)$ ones. The $t_{R}$ predicted was predicted using Sequence Specific Retention Calculator (SSRCalc) (http://hs2.proteome.ca/SSRCalc/SSRCalc.html; accessed: December 2019) [18] according to the mathematical formula introduced by Darewicz et al. [19]:

$$
\mathrm{t}_{\mathrm{R} \text { predicted }}=0.0002 \times\left(\mathrm{t}_{\mathrm{R} \mathrm{SSRCalc}}\right)^{3}-0.0085 \times\left(\mathrm{t}_{\mathrm{R} \mathrm{SSRCalc}}\right)^{2}+1.0415 \times\left(\mathrm{t}_{\mathrm{R} \text { SSRCalc }}\right)+8.6434
$$

where:

$t_{R}$ SSRCalc: retention time (min) calculated with Sequence Specific Retention Calculator (SSRCalc).

The specific parameters implemented in the software to obtain $t_{R}$ SSRCalc, like the retention time of the substance not adsorbed on the column (parameter "a"), the parameter dependent on the acetonitrile gradient (parameter " $\mathrm{b}$ "), pore diameter, column, and TFA concentration, were as described by Iwaniak et al. [9].

\section{Results}

\subsection{In Silico Analysis}

Many data concerning molecules can be found in databases [5]. The BIOPEP-UWM database of sensory peptides and amino acids [20] was used to analyze the in silico fragments released from soybean proteins. These peptides were searched for the presence of shorter bitter-tasting fragments, including indicators. The results are shown in Tables 1 and A1 (in the Appendix A). They include only released fragments that (a) contained bitter-tasting motifs and (b) consisted of four amino acid residues at a minimum. Shorter fragments were not discussed. They were di- and tri-peptides that could already match the sequences with a known taste sensation (i.e., bitterness).

Table 1. Number of parent peptides including these containing bitter-tasting indicators found in soybean protein sequences.

\begin{tabular}{cccc}
\hline \multicolumn{4}{c}{ Parent Peptides Released from Profilin Due to the Simulated Action of: } \\
\hline B ${ }^{\mathbf{1}}$ & $\mathbf{P}$ & PK \\
\hline Number of parent peptides/number of parent peptides containing bitter-tasting indicators \\
\hline $9 / 7$ & $5 / 2$ & $4 / 1$ & \\
\hline Total number of parent peptides/total number of parent peptides containing bitter-tasting indicators $=25 / 15$ \\
\hline \multicolumn{4}{c}{ Parent peptides released from globulin 7 S due to the simulated action of: } \\
\hline F & P & PK \\
\hline
\end{tabular}


Table 1. Cont.

\begin{tabular}{|c|c|c|}
\hline \multicolumn{3}{|c|}{ Number of parent peptides/number of parent peptides containing bitter-tasting indicators } \\
\hline $24 / 16$ & $20 / 16$ & $14 / 4$ \\
\hline \multicolumn{3}{|c|}{ Total number of parent peptides/total number of parent peptides containing bitter-tasting indicators $=68 / 41$} \\
\hline \multicolumn{3}{|c|}{ Parent peptides released from glycinin due to the simulated action of: } \\
\hline B & F & PK \\
\hline \multicolumn{3}{|c|}{ Number of parent peptides/number of parent peptides containing bitter-tasting indicators } \\
\hline 28/17 & $18 / 11$ & $17 / 8$ \\
\hline \multicolumn{3}{|c|}{ Total number of parent peptides/total number of parent peptides containing bitter-tasting indicators $=75 / 38$} \\
\hline \multicolumn{3}{|c|}{ Parent peptides released from $\beta$-conglycinin ( $\beta$-chain) due to the simulated action of: } \\
\hline B & $\mathbf{P}$ & PK \\
\hline \multicolumn{3}{|c|}{ Number of parent peptides/number of parent peptides containing bitter-tasting indicators } \\
\hline $30 / 18$ & $26 / 17$ & $13 / 4$ \\
\hline \multicolumn{3}{|c|}{ Total number of parent peptides/total number of parent peptides containing bitter-tasting indicators $=78 / 43$} \\
\hline \multicolumn{3}{|c|}{ Parent peptides released from $\beta$-conglycinin ( $\alpha$-chain) due to the simulated action of: } \\
\hline B & $\mathbf{F}$ & PK \\
\hline \multicolumn{3}{|c|}{ Number of parent peptides/number of parent peptides containing bitter-tasting indicators } \\
\hline $32 / 23$ & $27 / 17$ & $17 / 5$ \\
\hline Total number of & l number of parent peptides contai & dicators $=92 / 53$ \\
\hline
\end{tabular}

Regardless of the substrate and enzyme applied, all released fragments were the potential sources of motifs matching the sequences collected in the BIOPEP-UWM database and known in the literature as bitter-tasting. Thus, it was the premise to define them as parent peptides. Taking into consideration all enzymes applied in the study, the highest number of parent peptides was potentially released from $\beta$-conglycinin ( $\alpha$-chain), while profilin was the protein revealing the smallest number of peptides produced. Generally, the best in silico enzymatic potential aiming to produce parent peptides from all soybean protein sequences was represented by bromelain and papain. Other enzymes, i.e., ficin and proteinase $\mathrm{K}$, produced less parent peptides than the above enzymes. However, in most of the cases, proteinase $\mathrm{K}$ was predicted to be slightly better than ficin considering the number of peptides potentially released from soybean proteins. The most abundant potential sources of parent peptides containing one bitter-tasting indicator at minimum were: profilin ( 7 sequences, enzyme used: bromelain), 7S globulin (16 sequences each, enzymes used: bromelain and papain), glycinin (17 sequences, enzyme used: bromelain), $\beta$-conglycinin ( $\beta$-chain) (18 and 17 , enzymes used: bromelain and papain, respectively), and $\beta$-conglycinin ( $\alpha$-chain) (23 sequences, enzyme used: bromelain). The highest total number of parent peptides with encrypted bitter-tasting indicators, regardless of the enzyme used, was determined in the $\beta$ - and $\alpha$-chain of $\beta$-conglycinin (43 and 53 out of 78 and 93 generally released, respectively). Considering the enzymes that produced such parent peptides (i.e., with encrypted indicators), their ranking was as follows: bromelain $>$ papain $>$ ficin $>$ proteinase $\mathrm{K}$. The criterion in this ranking was the total number of parent peptides (i.e., the higher the number, the better place in the rank) containing one indicator of bitter taste at a minimum.

Dipeptides rather than tripeptides with or without the status of a bitter-tasting indicator were the great majority of motifs found in the parent peptides. Both two and three amino acid fragments were observed in the following peptides: ERPG-RP, RPG (source: profilin hydrolyzed with ficin); RQLEENLVVFDLA-VF, LE, LV, DL, EEN (source: 7S globulin hydrolyzed with proteinase K); SRPG-RP, RPG (source: 7S globulin hydrolyzed both with bromelain and ficin); EENL-EEN (source: 7S 
globulin hydrolyzed with proteinase K); VEENICTMK-VE, EEN (source: glycinin hydrolyzed with bromelain); ESEGGL-EGG, GL, GGL, EG-EGGSV-GR, EGG-EG; EGGL-EGG, EG, GGL, GL (source: glycinin hydrolyzed with proteinase K); LLLPH-LL, LL, LLL, PFPSILG-FP, PF, PFP, LG, IL (source: $\beta$-chain of $\beta$-conglycinin hydrolyzed with papain), EENL-EEN (source: $\beta$-chain of $\beta$-conglycinin hydrolyzed with proteinase K); EIPRPRPRPQHPEREPQQPG-RP, RP, RP, PR, PR, PR, EI; EEDEDEQPRPIPFPRPQPRQEEEHEQREEQEWPRK-RP, RP, PR, PR, PR, PR, FP, PF, PFP, PIP; SEEEDEDEDEEQDERQFPFPRPPHQK-PP, RP, PR, FP, FP, FPF, PF, PFP (source: $\alpha$-chain of $\beta$-conglycinin hydrolyzed with both bromelain and ficin); LLLPHFNSK-LL, LL, LLL; PVVVNA-VVV, VV, VV (source: $\alpha$-chain of $\beta$-conglycinin hydrolyzed with bromelain); PIPFPR-PR, FP, PF, PFP, PIP (source: $\alpha$-chain of $\beta$-conglycinin with papain); QFPFPR-PR, FP, FP, FPF, PF, PFP, PNTLLLPNH-LL, LL, LLL, LLLPH-LL, LL, LLL, and PVVVNA-VVV, VV, VV (source: $\alpha$-chain of $\beta$-conglycinin hydrolyzed with proteinase $\mathrm{K})$. Motifs in bold were the fragments with the status of being an indicator.

Some of the parent peptides in silico released from proteins contained such bitter-tasting motifs possessing or not possessing the status of indicators that fully or almost fully overlapped their whole sequences. They were for example encrypted in: VIRG-VI, RG (profilin, enzyme used: bromelain); EITLG-LG, EI (7S globulin, enzyme used: bromelain); DVLVIPLG-VL, VI, LG, LV (glycinin, enzymes used: bromelain and papain); VVLY/VV, VL (glycinin, enzyme used: bromelain); VVFK-VF, VV (glycinin, enzyme used: papain); EGGL-EGG, EG (glycinin, enzyme used: proteinase K); DIFL-FL, IF ( $\alpha$ - and $\beta$-chain of $\beta$-conglycinin, enzyme used: ficin); FVDA-FV, VD, DA ( $\alpha$ - and $\beta$-chain of $\beta$-conglycinin, enzyme used: papain); VLFG-VL, FG, LF, VIVE-VI, VE, IV; PFPSILG-FP, PF, PFP, LG, IL ( $\beta$-chain of $\beta$-conglycinin, enzyme used: papain); and NILE-LE, IL ( $\alpha$-chain of $\beta$-conglycinin, enzyme used: papain).

\subsection{Monitoring the Process of SPC Hydrolysis}

Taking into account the ranking of enzymes suitable for soybean protein hydrolysis, as well as the number of peptide bitter-tasting indicators produced, the next step was to produce soybean hydrolysates to compare in silico and in vitro results. Five samples representing 0-SPC, B-SPC, F-SPC, P-SPC, and PK-SPC were subjected to RP-HPLC separation to observe the progress in SPC hydrolysis (see Figure 1 and Table 2). Three major time segments could be distinguished in all chromatograms, namely: 0.00-13.99, 14.00-39.99, and 40.00-60.00 min. The first time segment contained the highest peak eluting for about $10 \mathrm{~min}$ (not shown in Figure 1). It was an injection peak that could contain non-retained substances like the buffers used for protein/hydrolysate solutions and low molecular weight compounds present in protein concentrates [9]. 


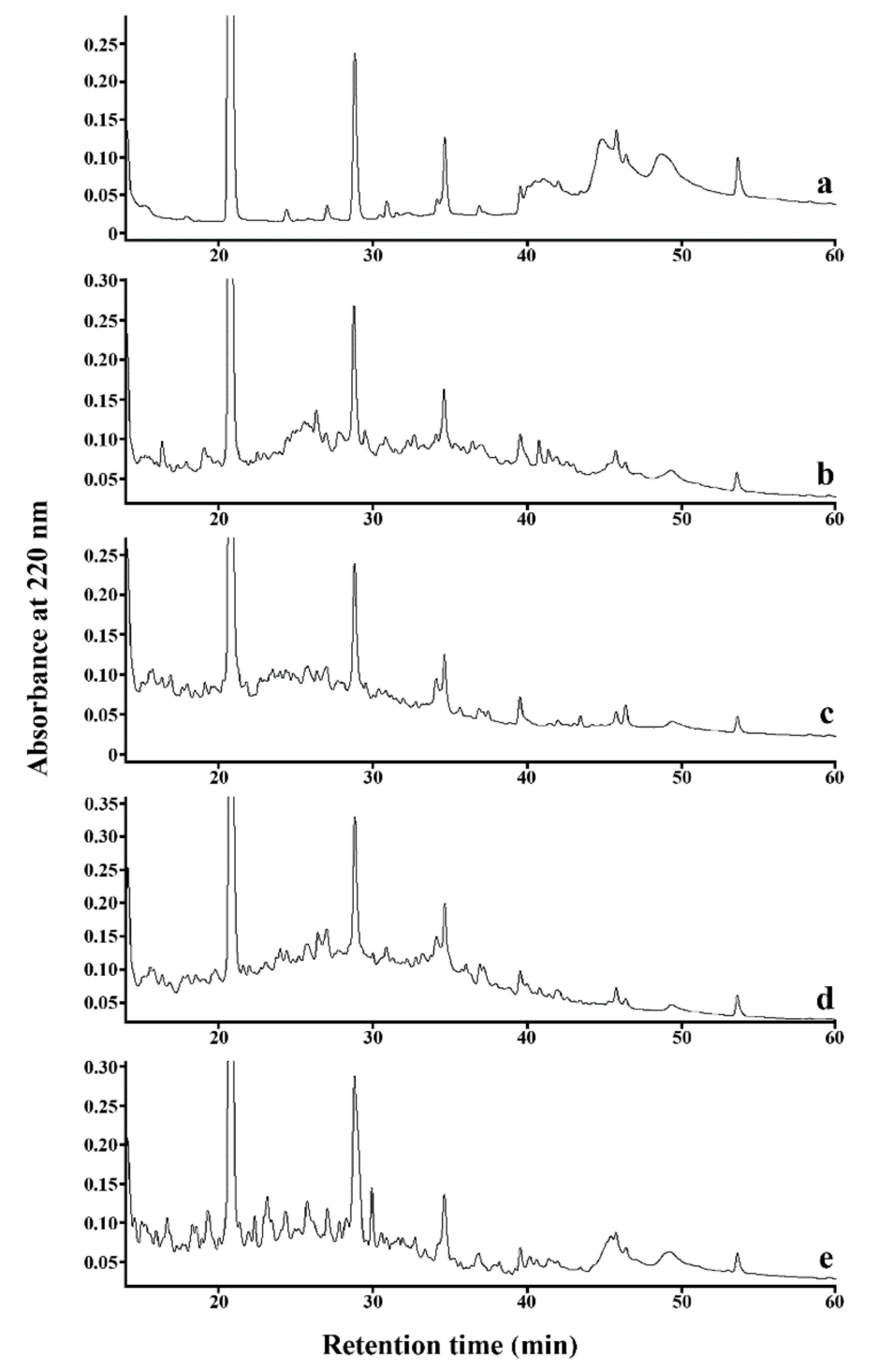

Figure 1. RP-HPLC (Reversed-Phase High Performance Liquid Chromatography) chromatograms of 0-soy protein concentrate (SPC) (a), B-SPC (b), F-SPC (c), P-SPC (d), and PK-SPC (e). Retention time range displayed in the Figure is between 14th and 60th minute. Chromatograms were acquired at $\lambda=220 \mathrm{~nm}$ as recommended by Visser et al. [21]. Abbreviations: 0-SPC-soy protein concentrate, B-SPC, F-SPC, P-SPC and PK-SPC: bromelain-, ficin-, papain-, and proteinase K-soybean protein hydrolysate, respectively.

Three major time segments could be distinguished in all chromatograms, namely: 0.00-13.99, 14.00-39.99, and 40.00-60.00 min. The first time segment contained the highest peak eluting for about $10 \mathrm{~min}$ (not shown in Figure 1). It was an injection peak that could contain non-retained substances like the buffers used for protein/hydrolysate solutions and low molecular weight compounds present in protein concentrates [9]. In our previous experiment [9], the shape and area of an injection peak were approximately the same in all chromatograms. Therefore, peaks that could be observed within in 0.00 and 13.99 min were not considered for further interpretation. Peaks eluting between 40.00 and 60.00 min corresponded to high molecular weight compounds, like, e.g., proteins [9,22]. On the other hand, the chromatogram of the unhydrolyzed SPC sample contained much material with a short retention time (Table 2) as compared with the unhydrolyzed milk protein concentrate analyzed in our previous experiment [9]. 
Table 2. Results of soybean protein hydrolysis as revealed by RP-HPLC (Reversed-Phase High Performance Liquid Chromatography).

\begin{tabular}{cccccc}
\hline \multirow{2}{*}{ Time Interval (min) } & \multicolumn{5}{c}{ Relative Area of Chromatographic Peaks (\%) } \\
\cline { 2 - 6 } & 0-SPC $^{\mathbf{2}}$ & B-SPC & F-SPC & P-SPC & PK-SPC \\
\hline $14.00-39.99$ & 50.1 & 83.3 & 96.7 & 93.6 & 85,2 \\
$40.00-60.00$ & 49.9 & 16.7 & 3.3 & 6.4 & 14.8 \\
C $^{3}$ & 0.0 & 4.0 & 14.2 & 6.8 & 2.4 \\
\hline
\end{tabular}

${ }^{1}$ The area of all peaks between 14 and $60 \mathrm{~min}$ is $100 \%$ (See Figure 1); ${ }^{2}$ 0-SPC, B-SPC, F-SPC, P-SPC, PK-SPC: non-hydrolyzed soy protein concentrate, soy protein concentrate hydrolyzed by bromelain, ficin, papain, or proteinase $\mathrm{K}$, respectively (see the Materials and Methods); ${ }^{3}$ Calculated according to Equation (1).

The area of peaks within the range of 14.00-39.99 min and 40.00-60.00 min was almost equal in this experiment (see Table 2), whereas for milk protein concentrate, the ratio of total peak area within a shorter $t_{R}$ range to a longer $t_{R}$ range was only ca. 0.05 [9]. Taking the above into account, we introduced the parameter $\mathrm{C}$ (Equation (1)) to compare results obtained during experiments performed with soybean proteins (this experiment) and milk proteins [9].

All chromatograms differed when looking at the time interval between 14.00 and $39.99 \mathrm{~min}$. It was also reflected in the differences between the percentages of total peak areas observed in these time segments (Table 2). The order of the $C$ parameter value was as follows: ficin $>$ papain $>$ proteinase $K>$ bromelain, which suggested that ficin was the most efficient among the proteolytic enzymes used for hydrolysis of the soybean protein concentrate. The order of susceptibility of milk protein concentrate (MPC) [9] was reported to be as follows: proteinase $\mathrm{K}(\mathrm{C}=19.6)>$ ficin $(\mathrm{C}=18.4)>$ papain $(\mathrm{C}=7.8)>$ bromelain $(C=1.6)$. Ficin seemed to be sufficient for hydrolysis of both MPC and SPC. Proteinase K hydrolyzed MPC more extensively than SPC. There was a relatively high amount of unhydrolyzed proteins after the hydrolysis of both protein preparations by bromelain.

\subsection{Identification of Peptides Likely to Be Bitter Derived from SPC Hydrolysates}

The results of identification of parent peptides in SPC hydrolysate samples are present in Table 3. The highest number of such peptides was identified in ficin and bromelain hydrolysates of SPC (five and four, respectively). Peptides derived from F-SPC matched the sequences originally encrypted in: $7 \mathrm{~S}$ globulin (1 peptide), glycinin (1 peptide), and $\beta$-chain of $\beta$-conglycinin ( 3 peptides). In turn, in the case of B-SPC, parent peptides were matched glycinin and the $\beta$-chain of $\beta$-conglycinin (two peptides each). One parent peptide was reported in papain SPC hydrolysate (source: $\alpha$-chain of $\beta$-conglycinin), whereas no peptides were found in proteinase $\mathrm{K}$ soybean protein hydrolysate. To summarize, the most effective enzymes producing in vitro the highest number of parent peptides were ficin $>$ bromelain $>$ papain. One parent sequence, i.e., LIVILNG, was identified in both B-SPC and P-SPC and matched both chains of $\beta$-conglycinin analyzed. All parent peptides identified in SPC hydrolysates contained motifs both with and without the status of a bitter-tasting indicator. Taking into consideration 339 parent peptides as the total sum of the sequences predicted as identified after in silico hydrolysis of soybean proteins and 10 parent peptides in vitro identified in SPC hydrolysates, the compatibility of the in silico and in vitro results of peptide identification was ca. $2.95 \%$. 
Table 3. Parent peptides identified in SPC hydrolysates using LC-MS/MS (Reversed-Phase High Performance Liquid Chromatography online with tandem Mass Spectrometry).

\begin{tabular}{|c|c|c|c|c|c|}
\hline Protein Source & Parent Peptide & $\begin{array}{l}\mathrm{m} / \mathrm{z} \\
(\mathrm{Da})\end{array}$ & $\begin{array}{c}t_{\mathrm{R} \text { predicted }} \\
(\mathrm{min})\end{array}$ & $\begin{array}{c}t_{R} \text { experimental } \\
\text { (min) }\end{array}$ & Motif $^{1}$ \\
\hline \multicolumn{6}{|c|}{ B-SPC $^{2}$} \\
\hline \multirow{2}{*}{ glycinin } & LSVISPK & 743.466 & 25.430 & 22.580 & PK, VI \\
\hline & DVLVIPLG & 825.509 & 43.140 & 39.540 & VL, VI, LG, LV 3 \\
\hline \multirow{2}{*}{$\begin{array}{l}\beta \text {-conglycinin } \\
(\beta \text {-chain) }\end{array}$} & LIVILNG & 741.487 & 38.280 & 39.390 & VI, IV, LI, IL \\
\hline & NPFLFG & 694.356 & 41.170 & 39.860 & FG, FL, LF, PF \\
\hline \multicolumn{6}{|c|}{ F-SPC } \\
\hline \multirow{2}{*}{$\begin{array}{l}\text { 7S globulin } \\
\text { glycinin }\end{array}$} & ISSTIV & 619.367 & 25.520 & 24.770 & IV \\
\hline & PQMIIV & 700.407 & 34.500 & 40.620 & II, IV \\
\hline \multirow{3}{*}{$\begin{array}{c}\beta \text {-conglycinin } \\
(\beta \text {-chain })\end{array}$} & PFPSIL & 673.392 & 27.530 & 27.050 & FP, PF, PFP, IL \\
\hline & DDFFL & 656.293 & 41.170 & 34.782 & FF, FL \\
\hline & FFEITPEK & 1010.520 & 35.950 & 36.200 & FF, EI \\
\hline \multicolumn{6}{|c|}{ P-SPC } \\
\hline $\begin{array}{c}\beta \text {-conglycinin } \\
(\alpha \text {-chain })\end{array}$ & LIVILNG & 741.487 & 38.280 & 39.390 & VI, IV, LI, IL \\
\hline
\end{tabular}

${ }^{1}$ Bitter-tasting indicators are given in bold; ${ }^{2}$ B-SPC, F-SPC, and P-SPC: bromelain-, ficin-, and papain-soybean protein hydrolysate, respectively (see the Materials and Methods); ${ }^{3}$ peptides with no indicator status are given in normal font.

Parent peptides were considered as identified in SPC hydrolysate if (a) the fragment ions were observed in the particular retention time $\left(t_{R}\right)$ and $(b) t_{R}$ predicted and $t_{R}$ experimental differed within the range of $\pm 10 \%[19,22]$. Peptide identification was understood as detection of a group of fragment (daughter) ions eluted in the same retention time [19,22,23]. Some of them could be formed via the non-sequential charge-directed pathway, leading to their formation by loss of water or the ammonia neutral molecule [24].

An example of a parent peptide that was identified in SPC hydrolysate fulfilling the above-mentioned criteria was the FFEITPEK sequence (Figure 2) containing two bitter-tasting indicators: FF and EL. The FFEITPEK was identified in an F-SPC sample and matched the $\beta$-chain of $\beta$-conglycinin. The $\mathrm{m} / \mathrm{z}$ of the precursor $(\mathrm{M}+\mathrm{H})^{+}$ion was $1010.500 \mathrm{Da}$. An intensive peak was observed in $\mathrm{t}_{\mathrm{R}}$ experimental $=36.200 \mathrm{~min}\left(\mathrm{t}_{\mathrm{R}}\right.$ predicted $\left.=35.950 \mathrm{~min}\right)$. Moreover, the detection of this peptide in an F-SPC sample was confirmed by the presence of eight fragment ions that eluted within the above-mentioned time. They were as follows: $\mathrm{X}_{4}{ }^{+}, \mathrm{C}_{4}{ }^{+}, \mathrm{B}_{8}{ }^{+}, \mathrm{B}_{7}{ }^{+}, \mathrm{B}_{6}{ }^{+}, \mathrm{A}_{8}{ }^{+}, \mathrm{Z}_{7}{ }^{+}$, and $\mathrm{Y}_{5}{ }^{+}$, and their intensity was expressed from several hundred $\left(\mathrm{Y}_{5}{ }^{+}\right.$ion) to thousands of counts (kCounts; all other fragment ions). 


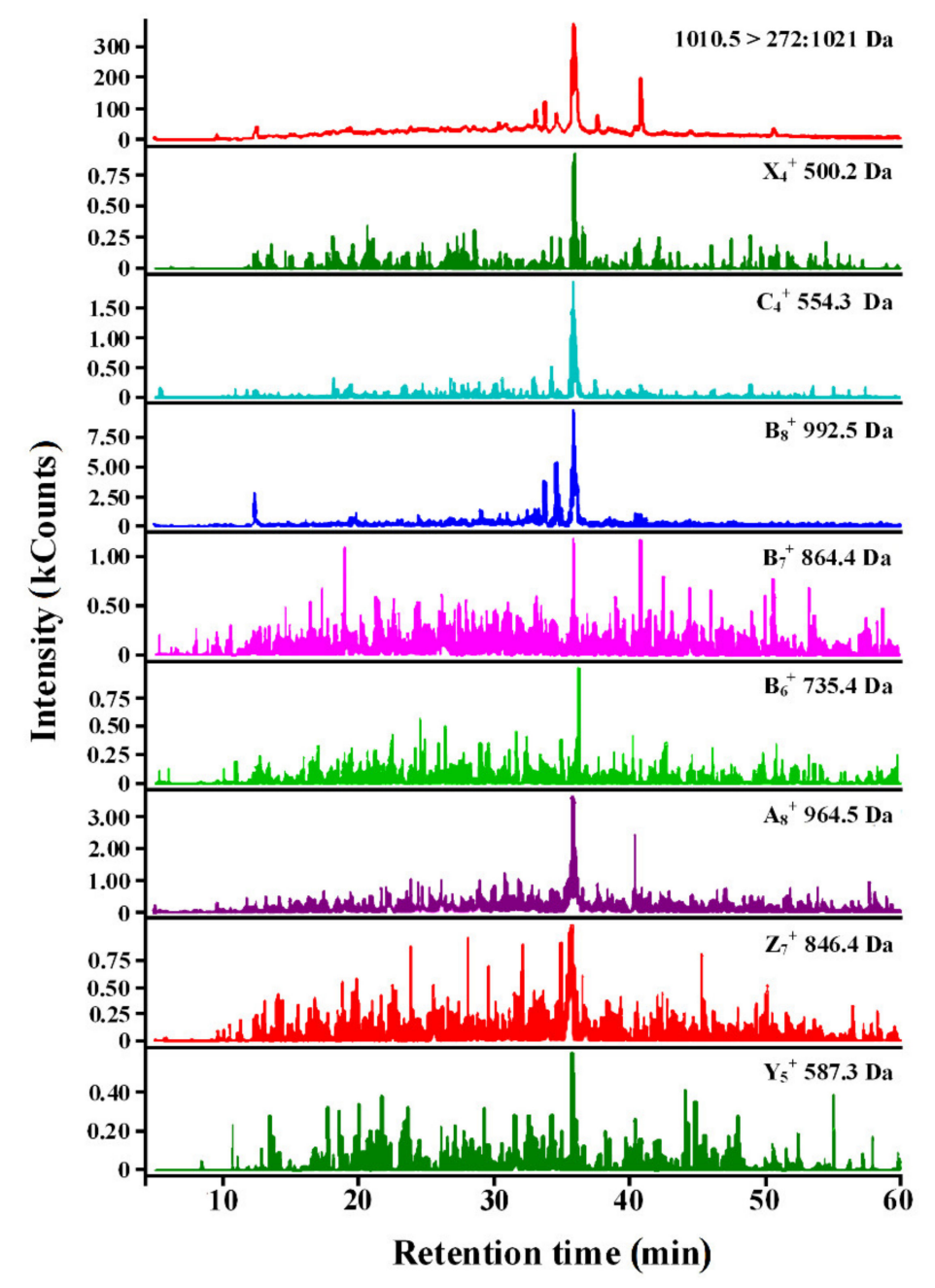

Figure 2. LC-MS/MS (Reversed-Phase High Performance Liquid Chromatography online with tandem Mass Spectrometry) chromatograms of total ion current (upper chromatogram: 1010.5 > 272:1021 Da) and daughter ions of the FFEITPEK peptide matching the $\beta$-conglycinin ( $\beta$-chain) fragment, identified among products of the soybean protein concentrate hydrolyzed by ficin. Nomenclature of daughter ions according to Roepstorff and Fohlman [25].

One peptide, i.e., DDFFL, with two encrypted indicators: FF and FL, was identified in F-SPC. It matched the $\beta$-chain of $\beta$-conglycinin. The most intensive peak eluted for about $35 \mathrm{~min}$ (see Figure 3 ); however, the theoretical retention time calculated for this peptide was $41.170 \mathrm{~min}$. The difference between $t_{R \text { predicted }}$ and $t_{R}$ experimental exceeded the threshold value of $10 \%$ for defining the peptide as identified [21]. The $\mathrm{m} / \mathrm{z}$ of the $(\mathrm{M}+\mathrm{H})^{+}$precursor ion of the DDFFL peptide was $656.300 \mathrm{Da}$, and nine intensive peaks were observed in $35 \mathrm{~min}$. They were the following fragment ions: $\mathrm{X}_{2}{ }^{+}$, $\mathrm{C}_{4}{ }^{+}, \mathrm{B}_{4}{ }^{+}, \mathrm{B}_{3}{ }^{+}, \mathrm{B}_{2}{ }^{+}, \mathrm{A}_{3}{ }^{+}, \mathrm{A}_{5}{ }^{+}, \mathrm{Z}_{2}{ }^{+}$, and $\mathrm{Z}_{4}{ }^{+}$. All of them occurred in thousands of counts. Thus, the DDFFL peptide was considered as identified in the F-SPC sample. Some differences between predicted and experimental RT (retention time) were observed during the microLC-ToF-MS (i.e., micro liquid chromatography time-of-flight mass spectrometry) identification of bioactive peptides derived from yoghurt. According to Kunda et al. [26], such an unequivocal identification based on retention time differences is called Type 1 identity conflict. 


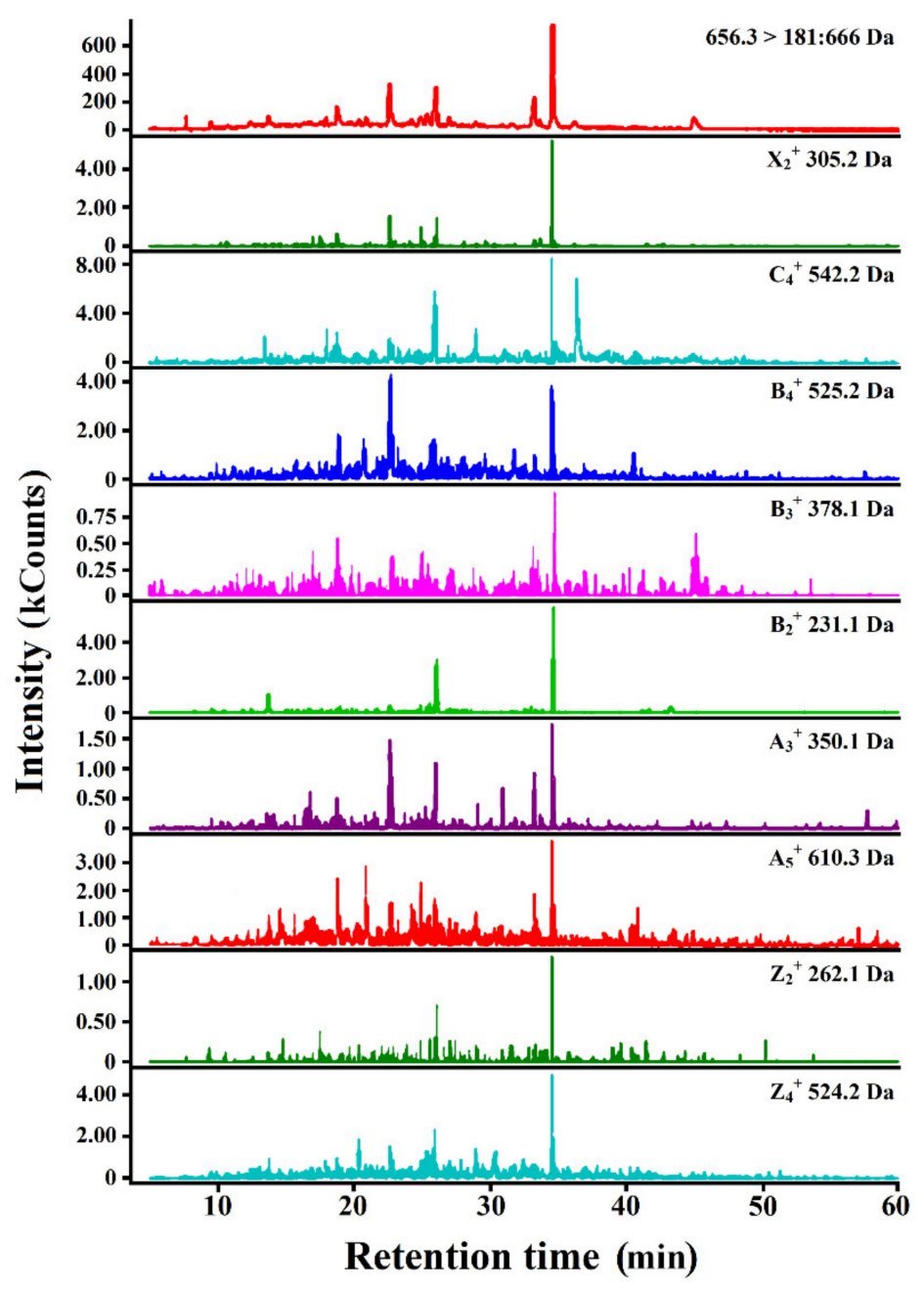

Figure 3. LC-MS/MS chromatograms of total ion current (upper chromatogram-656.3 > 181: $666 \mathrm{Da}$ ) and daughter ions of the DDFFL peptide matching the $\beta$-conglycinin ( $\beta$-chain) fragment identified among products of hydrolysis of soybean protein concentrate by ficin. Nomenclature of daughter ions according to Roepstorff and Fohlman [25].

It is well documented in the literature that some biopeptides impart bitter taste, which is a limitation when thinking about their implementation in foods supporting the prophylaxis of diet-related diseases [27]. This especially concerns ACE-inhibiting peptides [28]. Some of the bitter-tasting motifs encrypted in all parent peptides identified in SPC hydrolysates showed an additional biological effect as judged by BIOPEP-UWM database screening (see Table 4). A more comprehensive list of the bioactivities of bitter peptides may be found in the Supplement to our previous review [29]. It was evidenced that the application of different proteases or the fermentation process of soybean proteins leads to obtaining the unique peptide profiles exhibiting, e.g., antihypertensive [30,31], hypocholesterolemic [32], antioxidative [33], and antidiabetic [1] effects. The majority of bitter fragments occurring in parent peptides that were identified in all SPC hydrolysates were associated with ACE-, DPP-IV-, and DPP-III-inhibiting or glucose uptake-stimulating activity. The first activity plays an important role in the reduction of blood pressure [34], while DPP-IV inhibitors are responsible for the antidiabetic effect [35], and the latter ones are involved in prolonging the action of endogenously released or exogenously applied enkephalins (i.e., a promising agent in chronic pain management) [36]. 
Table 4. Additional bioactivity of bitter motifs found in parent peptides identified in SPC (soybean protein concentrate) hydrolysate samples.

\begin{tabular}{|c|c|c|}
\hline Parent Peptide & Motif ${ }^{1}$ & Bioactivities \\
\hline LSVISPK & PK; VI, SV, SP & DPP IV inhibitor \\
\hline DVLVIPLG & $\begin{array}{l}\text { VL; VI; LV; IP; PL } \\
\text { LG; PL; IP; PLG } \\
\text { PLG } \\
\text { VL; LV }\end{array}$ & $\begin{array}{c}\text { DPP IV inhibitor } \\
\text { ACE inhibitor } \\
\text { Opioid } \\
\text { Stimulating glucose uptake }\end{array}$ \\
\hline LIVILNG & $\begin{array}{l}\text { VI; LI; IL; LN; NG } \\
\text { IL; LN; NG } \\
\text { IV; IL; LI }\end{array}$ & $\begin{array}{c}\text { DPP IV inhibitor } \\
\text { ACE inhibitor } \\
\text { Stimulating glucose uptake }\end{array}$ \\
\hline NPFLFG & $\begin{array}{c}\text { FL; PF; NP } \\
\text { FL; PF } \\
\text { FG; LF }\end{array}$ & $\begin{array}{l}\text { DPP IV inhibitor } \\
\text { DPP III inhibitor } \\
\text { ACE inhibitor }\end{array}$ \\
\hline ISSTIV & $\begin{array}{l}\text { IV } \\
\text { ST } \\
\text { TI }\end{array}$ & $\begin{array}{c}\text { Stimulating glucose uptake } \\
\text { ACE inhibitor } \\
\text { DPP IV inhibitor }\end{array}$ \\
\hline PQMIIV & $\begin{array}{l}\text { II; MI; PQ } \\
\text { IV; II } \\
\text { PQ }\end{array}$ & $\begin{array}{c}\text { DPP IV inhibitor } \\
\text { Stimulating glucose uptake } \\
\text { ACE inhibitor }\end{array}$ \\
\hline PFPSIL & $\begin{array}{c}\text { FP; PFP; IL } \\
\text { FP; PF; IL; PS; SI } \\
\text { IL } \\
\text { PF }\end{array}$ & $\begin{array}{c}\text { ACE inhibitor } \\
\text { DPP IV inhibitor } \\
\text { Stimulating glucose uptake } \\
\text { DPP III inhibitor }\end{array}$ \\
\hline DDFFL & $\begin{array}{c}\text { FL } \\
\text { FFL; DF }\end{array}$ & $\begin{array}{l}\text { DPP IV inhibitor; DPP III inhibitor } \\
\text { ACE inhibitor }\end{array}$ \\
\hline FFEITPEK & $\begin{array}{l}\text { EI; TP; EK } \\
\text { PE }\end{array}$ & $\begin{array}{l}\text { DPP IV inhibitor; ACE inhibitor } \\
\text { DPP III inhibitor }\end{array}$ \\
\hline
\end{tabular}

${ }^{1}$ Bitter-tasting indicators are given in bold, and peptides with no indicator status are given in normal font. Abbreviations: ACE, Angiotensin-converting enzyme (EC 3.4.15.1); DPP III, dipeptidyl peptidase III (EC 3.4.14.4); DPP IV, dipeptidyl peptidase IV (EC 3.4.14.5).

\section{Discussion}

The study above was divided into two steps: bioinformatic and experimental analyses. According to Tu et al. [37], bioinformatic analyses help in better understanding biological data and hence their application in food and nutrition increases. Moreover, the fact of the presence of some unique fragments within the primary structures of peptides underlies their different biofunctions. Bioinformatic studies enable minimizing the number of experiments involved to determine the impact of the structure of a peptide on its biological function [37]. Moreover, in silico experiments are relatively easy and less costly to carry out, and they do not require reagent and sample preparation [38]. Combining the bioinformatics with an experimental verification of the results is, in turn, a kind of methodology called an integrated (i.e., hybrid) approach. This term was introduced by Udenigwe [38], and ever since, many studies on bioactive peptides, including the present one, have implemented procedures to solve a problem using databases of biological information and then involving laboratory analyses [5].

To the best of our knowledge, the hybrid and fragmentomic approaches have not been applied so far to analyze the potential of soybean proteins as the reservoir of bitter-tasting motifs. Moreover, our protocol of research was partially based on positive selection [39], i.e., finding in the protein the sequential motifs with already known biological function (i.e., provided in a database). Fu et al. [39] employed this strategy to evaluate the potential of patatin (Solanum tuberosum; potato protein) as a source of biopeptides. The biological dataset (peptide sequences) was acquired from the BIOPEP-UWM database. The novel aspect of our research was the use of the positive selection to define bitter-tasting 
motifs (especially peptide indicators) in parent sequences potentially released from soybean. According to Agyei et al. [40], the prediction of the bitter taste of foods may support the development of the procedures for masking this taste. Although such a strategy of research has some limitations, it may help discover new peptides [40]. This is a universal approach that may be applicable to in silico assessment of any protein as the reservoir of peptides with any biological function. Although the term "fragmentomics" is not widely used in publications, it represents one of the common contemporary strategies of research on bioactive peptides. Recent applications of fragmentomics concerning the bioactivity of peptides derived from various food sources have been described by Sutopo et al. [41], Alcaide-Hidalgo et al. [42], and Kinariwala et al. [43].

As was said above, the substrate for bioinformatic analyses was the sequences of five soybean proteins, which were subjected to the theoretical hydrolysis using four enzymes: bromelain, ficin, papain, and proteinase $\mathrm{K}$. According to the literature, soybean is widely used in human nutrition and animal feeding due to the high biological value of its proteins. Moreover, it is the least expensive source of protein, which may be helpful in solving feeding and agronomical problems [44]. However, hydrolysis of proteins, also these from soybean, contributes to the production of peptides that taste bitter and are not accepted by Western consumers, even if they offer a health-beneficial value $[45,46]$. Our initial bioinformatic predictions also confirmed the potential of soybean proteins as the richest sources of bitter-tasting sequences when comparing them to the other sequences of proteins derived from grains, oil, and leguminous plants (21 sequences in total; data not shown). This comparison was made based on one of the criteria serving to evaluate proteins as sources of peptides with a particular bioactivity (i.e., bitterness in this case) defined as the frequency of the occurrence of bitter peptides in a protein chain, a parameter called " $\mathrm{A}$ " available in the BIOPEP-UWM database (data not shown). According to the scientific reports, the higher the A, the better the potential of a protein to release peptides with a specified biofunction [47]. A similar trend was successfully followed by Keska and Stadnik [48], who analyzed 16 sequences of porcine proteins as sources of tastant peptides. The potency of myofibrillar and sarcoplasmic proteins was estimated based on the values of a parameter called "abundance of taste-active peptides/amino acids in a protein sequence" $\left(A_{R}\right)$, being mathematically a twin version of the $A$ value provided in the BIOPEP-UWM database. $A_{R}$ calculations enabled a theoretical indication about which of the porcine proteins may have the strongest impact on the sensory properties of meat products [48].

Most of the endopeptidases that are applied to produce soybean protein hydrolysates are derived from microorganisms and/or plants. Among them, bromelain, papain, and ficin are stated as the enzymes with large scale availability when comparing them to the proteases originating from animal sources [49]. Although, the analysis of the scientific reports did not show any data about the possible application of the fourth enzyme, i.e., proteinase K, aiming to produce peptides from soybean proteins, this enzyme was included on the in silico part of the study. This decision resulted from the comparison of the effectiveness of almost all enzymes available in BIOPEP-UWM (expressed as the number of peptides released) to produce potentially bioactive peptides, especially tastant peptides (data not shown). The comparison excluded pepsin, trypsin, and chymotrypsin as digestive tract enzymes. They naturally digest proteins when ingested [46].

The results of the enzymatic release of a fragment containing bitter-tasting motifs with and without the status of an indicator are presented in Table 1. This way of data analysis fits the research trend of fragmentomics relying on ascribing the "unknown" biological function of a molecule to the known function of motifs occurring in it and is based on positive selection (see above) [7,39]. In our study, the molecule with no predicted function was a compound called the parent peptide, whereas the motif deciding its possible function was the bitter-tasting peptide. Thus, to be consistent with the fragmentomic idea, data analysis was limited to the released peptides composed of at least four amino acids. Data about the bitterness of such peptides were implemented from the BIOPEP-UWM database of sensory peptides and amino acids [20]. Based on the MLR stepwise regression analysis, some of these peptides were selected as bitter-tasting peptidic indicators, i.e., peptides with approximate predicted 


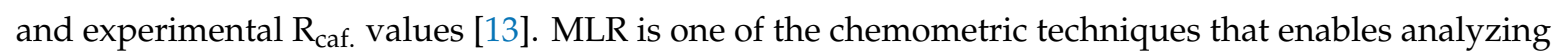
the relationship between the structure (i.e., sequence) of a peptide and its biological activity, which is called QSAR (i.e., quantitative structure-activity relationship) [50]. According to Chanput et al. [51], the QSAR methodology is one of the important methods for the analysis of the functionality of peptides. The results of MLR showed that the bitter taste of a peptide is attributable to the presence of some specific residues, like Leu, Ile, Val, Phe, and Tyr [13]. This observation was consistent with the statements of other authors studying bitter peptides using QSAR techniques [52].

Ample in silico studies have been undertaken to evaluate proteins as sources of peptides with various bioactivities using the BIOPEP-UWM database [12]. The analysis of data concerning theoretical release of peptides can be considered from several perspectives, namely: how the length of motifs affects their match to the parent peptides; how the length of the parent peptide contributes to the presence of a bioactive motif in it; and finally, how the length of protein affects the number of parent peptides to be produced. As could be seen, parent peptides that were theoretically released from soybean proteins were the sources of bitter motifs with and/or without the status of an indicator. The great majority of such motifs were dipeptides. According to Iwaniak and Dziuba [53], the match of the motif to the query sequence depends on its chain length (i.e., the shorter, the better). The potential of parent peptides as sources of peptides with a specified function can be quantitatively evaluated using the A parameter (see above). So far, the discriminant A had been successfully applied to compare proteins according to the rule: the higher the A value, the better source of biopeptides the protein of interest is [47]. As regards the parent sequences, no regularities were observed between their chain length and the increasing tendency in the occurrence of bitter-tasting motifs. An example in this case is the DIFL/FL, IF peptide (from $\beta$-conglycinin $\beta$-chain hydrolyzed with ficin). Its A value was 0.500. The ETSFHSEFEEIN peptide was derived from the same source as DIFL and contained two bitter-tasting motifs: EI, EF. Hence, its A value was 0.166 . In the case of parent peptides, also their particular amino acid composition is crucial to predict their biological function including the likelihood of them to taste bitter. To exemplify it, these two criteria were fulfilled for parent peptide FSHNILETSFHSEFEEINRVLFG/FG, LF, VL, LE, IL, EI, EF theoretically released from $\beta$-conglycinin $\beta$-chain hydrolyzed with bromelain. The A value for this peptide was 0.304 . Finally, those protein sequences that had the longest amino acid chains represented the best potential to produce several tens of peptides. This rule also suggested the higher probability of peptide release in laboratory conditions [54]. In the case of the in silico results obtained, the highest number of parent peptides likely to be bitter due to the presence of bitter-tasting motifs was produced from $\alpha$ - and $\beta$-chains of soybean $\beta$-conglycinins. According to literature reports, glycinin and $\beta$-conglycinin represent about $65-85 \%$ of the total soybean proteins, and they are known as good reservoirs of bioactive peptides [46].

All in silico results encouraged us to continue studies using laboratory analyses, starting from the hydrolysis of SPC. Hydrolysis was conducted for $3 \%(\mathrm{w} / \mathrm{v})$ water solutions of SPC. According to Arboleda et al. [55], commercial soybean preparations available in the form of powder (as used in our study) are highly soluble in water if the protein solution does not exceed $20 \%$. The enzyme-to-substrate ratio for all four samples to be hydrolyzed was 1:100 (protein; w/w). Such proportions of enzymes and substrate were applied by Peñta-Ramos and Xiong [15] for the hydrolysis of soy protein isolate using crude enzymes, like papain, pepsin, and chymotrypsin, as well as commercial proteases to measure the antioxidant activity of hydrolysates.

RP-HPLC comparison of the percentages of the peak areas of all SPC hydrolysate samples allowed monitoring the process of their hydrolysis. The analysis of RP-HPLC chromatograms was successfully applied to observe the progress of hydrolysis of carp, herring, and milk proteins $[9,22]$. The changes in peak areas observed in different time intervals enabled concluding that SPC hydrolysis took place and allowed identifying parent peptides in the SPC hydrolysate samples using RP-HPLC-MS/MS.

Discrepancies were observed between the number of parent peptides that were identified in silico and in vitro, which is a common fact in the literature [56]. One of the possible reasons behind differences between the in silico and in vitro results was the fact that the sequences produced using the 
in silico method had to match those already present in the database [9]. The results of this work showed the successful identification of nine parent peptides in total (see Table 3) in all SPC hydrolysates, whereas the in silico simulation of hydrolysis of soybean sequences allowed obtaining 339 parent peptides. Bucholska and Minkiewicz [22] defined the likely reasons that may affect the unsuccessful identification of peptides in a hydrolysate sample. They included no detectable amount of peptide in the sample (e.g., if some peptide bonds likely to be cleaved are actually resistant to hydrolysis) and no detectable fragmentation in an ion trap mass spectrometer. Additionally, peptides identified in SPC hydrolysates are defined as proteotypic peptides, and their identification is dependent on the mass spectrometer used. Finally, there is no method that would serve for the identification of all possible peptides in a protein hydrolysate [22]. The last reason for the discrepancy might be the fact that in silico predictions assume that all peptide bonds are hydrolyzed in a protein chain.

Ficin was the most effective enzyme for producing peptides in vitro, whereas bromelain in the theoretical production of parent peptides likely to be bitter. Enzyme rankings were as follows: bromelain $>$ papain $>$ ficin $>$ proteinase $\mathrm{K}$ (in silico results) and ficin $>$ bromelain $>$ papain (in vitro results). There was no correlation between the results of RP-HPLC (C parameter from Table 2) and the number of identified peptides with bitterness indicators. Despite the differences between these rankings, the richest source of parent peptides produced by the applied enzymes turned out to be conglycinins. No parent peptides that were identified in all SPH matched the sequences known as bitter themselves. Moreover, none of these peptides were found as bioactive themselves (see Table 4). Iwaniak et al. [9] identified some parent peptides likely to be bitter in milk protein hydrolysates. For example, the PFPIIV peptide matched the bitter-tasting sequence in the BIOPEP-UWM sensory peptide database (peptide ID in the database: 195). PFPIIV was known as bitter itself, contained PFP, PF, IV, FP, II bitter motifs, and was identified in bromelain, ficin, and papain hydrolysates of milk protein concentrate. Moreover, two milk protein-derived peptides: TTMPLW (source: papain hydrolysate) and VLPVPQK (source: bromelain hydrolysate), served additional biofunctions. Based on information found in the BIOPEP-UWM bioactive peptide database, the first sequence exhibited opioid, immunomodulating, and ACE inhibitory effects (peptide IDs in the database: 3127, 8172, and 3520, respectively). The second one was reported as an antioxidative agent (peptide ID: 7877) [9]. As was said above, bitterness associated with bioactive peptides may be found as an unwanted property when thinking about the production of food that is health-beneficial and sensorially-attractive [57]. Hence, our concept relying on the fragmentomic idea of research was useful to: (1) find out if the parent peptides were bitter/bioactive themselves or (2) motifs like, e.g., peptidic bitterness indicators that are encrypted in a sequence exhibiting other activities, may "suggest" the bioactivity/taste of the parent sequence. This concept shows also the potential of enzymes to produce motifs supposed to be bioactive/bitter. The enzymes' potential to produce unwanted peptides may initially be also an indicative criterion of their "negative" selection (i.e., rejection) when considering the production of non- or less bitter hydrolysates. However, according to Fu et al. [39], it needs to be noted that although the theoretical predictions concerning the potential of proteins as sources of peptides and enzymes involved in their production can support further research, such predictions are never $100 \%$ consistent with experimental results. This is also true concerning our concept.

The discrepancies between in silico and in vitro results may be associated with the specificity of bioinformatic and experimental analyses. Bioinformatic issues are related to the tools used for predictions, especially databases of biological information. Many data on biological peptides are published every year. Our quick search in Scopus (accessed: January 2020) showed 188 records reflecting the number of articles that were published in 2018 (about 15.7 per month) and contained the following exact words as queries "bioactive peptides AND food proteins". The same query words were used to the search for the articles published in 2019. This simple search showed 241 papers published in 2019 (i.e., 20.08 per month). Both searches were limited to articles, and they excluded conference abstracts. Thus, it may appear that there are some biological activities represented by both parent peptides and their bitter-tasting motifs that were published after this paper was released, 
and thus, they were not included when we ran these studies. A similar search for the latest publications concerning sensory peptides showed no new sequences with confirmed bitterness that could be downloaded to the BIOPEP-UWM database and used for further analyses. Thus, our results concerning the presence of bitter-tasting motifs in parent sequences seemed to be relatively steady. Nevertheless, it is recommended to carry out the regular update of databases [38], as well as to use curated databases, like, e.g., BIOPEP-UWM [12].

Experimental issues that possibly affect the differences between in silico and in vitro results may be related to the hydrolysis of protein. Theoretical hydrolysis via bioinformatic tools, including BIOPEP-UWM, is based on the specificity of an enzyme, and hypothetically, all peptide bonds are accessible to enzymatic cleavage [58]. The cleavage of peptide bonds is one of the descriptors characterizing the nature of the enzyme [59]. However, the effectiveness of enzymatic hydrolysis depends also on the temperature, the $\mathrm{pH}$, the enzyme-to-substrate ratio [46], and the types of the molecules affecting the inhibition of the enzyme [60], which are difficult parameters to be included as the "elements" of programs serving for theoretical proteolysis. Moreover, such predictive hydrolysis is relatively simple, especially when the protein is not chemically modified. For example, glycosylated amino acids present in a protein may block the breakdown of a peptide bond in experimental conditions [61]. Additionally, the computer simulation of hydrolysis does not consider the complexity of the protein structure that might hinder its interactions with proteolytic enzyme [58]. Rawlings [62] added to this list some other factors likely to affect the results of proteolysis carried out in experimental conditions, i.e.: location of the enzyme and substrate in different extra- and intra-cellular regions and the involvement of inhibitors. They are not considered by programs for theoretical hydrolysis. In turn, Ashaolu [46] highlighted that proteolysis of soybean carried out in experimental conditions enabled the reduction of waste, establishing the mild conditions of reaction, avoiding unwanted reactions; however, the obstacle is the cost of enzymes, as well as the recovery and/or removal of bitter taste [46].

Despite the discrepancies between the in silico and in vitro results of the hydrolysis of proteins aiming to produce biopeptides, scientists use the hybrid approach more often [63]. Iwaniak et al. [9] applied this protocol to hydrolyze milk protein concentrate using exact enzymes as in the study above. They showed that the results of experimental and theoretical analyses differed. Twenty-eight peptides with the potential to affect the bitter taste of hydrolysates were produced in laboratory conditions, which was consistent by ca. $12 \%$ with computer simulations (226 parent peptides identified in silico). Darewicz et al. [19] used the in silico/in vitro/ex vivo analyses to study the potential of salmon (Salmo salar) proteins as the source of ACE inhibitory peptides. To verify the in silico results in laboratory conditions, protein hydrolysis was carried out in vitro (with commercial enzymes) and ex vivo (using digestive juices from volunteers). It was confirmed that some ACE inhibitors were identified in both hydrolysates; however, some of them were observed either in the ex vivo or in the in vitro salmon protein hydrolysate [19].

To recapitulate, the comparison of in silico and in vitro results also differed in our experiment concerning soybean proteins as the material. Nevertheless, they still can be supportive when predicting the bitter-tasting properties of parent peptides based on the fragmentomic approach. Citing the words of Li et al. [64], "the BIOPEP-UWM database is a useful data source that supports the analysis of connections between peptide molecular structures and their sensory properties, and additionally enables users to build a potential sensory profile of peptides". The BIOPEP-UWM database was applied to predict the umami taste of peptides derived from clam M. meretrix Linnaeus [64]. Garcia-Vaquero et al. [45] applied the hybrid approach to assess the bitter taste properties of novel peptide ACE inhibitors derived from U. lactuca (green algae). To this end, green algae proteins were in vitro (enzyme used: papain) and in silico (tool used: PeptideCutter) hydrolyzed. The bitterness of peptides that were identified in the hydrolysates of $U$. lactuca was predicted based on the calculation of the Q-value introduced by Ney [65]. The Q-value is empirically associated with the hydrophobicity of each amino acid in a peptide sequence. Such a correlation is defined as the Q-rule, according to which the peptide likely to be bitter should have $Q$ over $1400 \mathrm{cal} / \mathrm{mole}$ [66]. Based on the Q-rule, it was found that the following 
green algae-originating sequences: SAGVLPWK (GV, VL), GAAPTPPSPPPATKPSTPPKPPT (PK, KP, PPP), IECCLLFALV (LL), PVGCLPK (PK), DAVEIWRVK (VE, EI), DEVIPGAL (VI), PKPPALCN (PK, KP), and PPNPPNPPN, were characterized with Q-values ranging from 1440 to $1743.33 \mathrm{cal} / \mathrm{mol}$, which suggested they could taste bitter [45]. Defining these sequences as "parent peptides" and implementing the fragmentomic idea, we found that seven out of eight such peptides contained motifs (in bold) described as bitter-tasting indicators (provided in brackets). Working the opposite way, we calculated Q-values (cal/mole) for all parent peptides that were experimentally identified in SPC hydrolysates. They were as follows: 1611.43 (LSVISPK), 1793.75 (DVLVIPLG), 1780.00 (LIVILNG), 1721.66 (NPFLFG), 1358.33 (ISSTIV), 1908.33 (PQMIIV), 2220.00 (PFPSIL), 1760.00 (DDFFL), and 1741.25 (FFEITPEK). Only one peptide (ISSTIV) had the Q-value below $1400 \mathrm{cal} / \mathrm{mole}$. Based on the Q-value, the other peptides identified in SPC hydrolysates containing bitter-tasting motifs with and without the status of an indicator could be classified as bitter. However, some studies on the bitterness of peptides indicated that some of them with the Q-value lower than $1400 \mathrm{cal} / \mathrm{mole}$ also tasted bitter. An example of such a peptide is the EVLN sequence (Q-value $=1162.5 \mathrm{cal} / \mathrm{mole}$ ) identified in cheddar cheese and matching $\alpha_{\mathrm{s} 1}$-casein as a protein precursor [67]. Moreover, taking into account our point of view, this peptide contains the VL bitter-tasting motif, which may be crucial in defining the taste of the whole sequence. Another aspect related to parent peptides likely to be bitter is their size [68]. According to the literature, peptide fractions of soybean protein hydrolysates with molecular weight ranging from 1.9 to $3.3 \mathrm{kDa}$ were characterized by the highest bitterness, whereas the bitterness of other fractions with lower or higher molecular weight than indicated above was milder [68]. Our parent peptides differed in the molecular weight. Thus, the strategy for the elimination of the unwanted taste of a hydrolysate should also be based on the knowledge concerning the amino acid composition of peptides [49]. This point of view fits the fragmentomic idea of the research presented in this article.

The example of positive selection [39] (see above) can be also applicable to enzymes used for the hydrolysis of protein to release peptides. Briefly, the enzyme that is in silico the most effective at producing bioactive peptides may be selected for the hydrolysis of proteins in experimental conditions. This allows identifying the most effective enzymes releasing peptides likely to be bitter (i.e., possessing an unwanted property) from soybean proteins. When thinking about bitterness, such a strategy of research may be the starting point for negative selection, which is the elimination of such enzymes to avoid the production of peptides with the undesired taste. However, the elimination of the enzyme might be problematic if it produces many bitter sequences exhibiting an additional, health-beneficial effect. In such a case, some further procedures should be considered to reduce the bitterness of bioactive hydrolysates. An example of such a procedure is the treatment with exopeptidases [69]. Cheung et al. [69] hydrolyzed whey protein isolates with different commercial endopeptidases and obtained a bitter-tasting ACE-inhibitory hydrolysate. To reduce its bitterness, the hydrolysis was extended with exopeptidases treatment. The taste of this hydrolysate was then more acceptable because of the removal of terminal residues as a result of exopeptidase action [69].

To summarize, our idea of research showed that the potential property of peptides released from proteins might be predicted based on the presence of sequential motifs with already known function (so-called positive selection). This helps understanding some relationships between the structure of a molecule and its activity (e.g., bitter taste). It needs to be noted that although it is possible to prognose the potential of released peptides to taste bitter, such a statement should be confirmed in laboratory conditions [70].

Our methodology might be an effective and universal way to analyze the biological functions of peptides found in protein hydrolysates. Although each of the methodologies contributing to the discovery of bioactive peptides has some limitations and specific character, the strategies involving the wide range of in silico approaches combined with conventional studies can play an important role in the generation and discovery of new peptides [71]. Thus, the employment of several methods for the theoretical prediction of the bitterness of a molecule is inscribed into this trend and is highly recommended. 


\section{Conclusions}

Results concerning the production of peptides likely to be bitter derived from soybean proteins showed the discrepancies between in silico and in vitro results. These discrepancies concerned the number of parent peptides released when applying theoretical and experimental hydrolysis, as well as the ranking of enzymes effective in the production of peptides possessing di- and tri-peptide motifs defined as indicators. The compatibility percentage of in silico and in vitro results was less than $3 \%$. However, all parent peptides that were identified in SPC hydrolysates contained motifs having or not the status of bitter-tasting indicators. Their Q-values suggested they could taste bitter. Thus, it could be concluded that the fragmentomic idea of research analyzing the composition of a parent sequence might be a supportive tool for the prediction of the taste of foods. Moreover, it broadens the knowledge about the structural nature of peptides as bioactive/tastant molecules. However, it is postulated that such statements concerning the peptides likely to be bitter should be evaluated experimentally.

Author Contributions: Conceptualization, A.I.; methodology, A.I., M.H., and P.M.; investigation, A.I., M.H., J.B., P.M., and M.D.; resources, M.D. and P.M.; writing, A.I. and M.H.; writing, review and editing, A.I. and M.D.; funding acquisition, M.D. All authors have read and agreed to the published version of the manuscript.

Funding: Project financially supported by the Minister of Science and Higher Education in the range of the program entitled "Regional Initiative of Excellence" for the years 2019-2022, Project No. 010/RID/2018/19, amount of funding 12,000,000 PLN, as well as the funds of the University of Warmia and Mazury in Olsztyn (Project No. 17.610.014-110).

Conflicts of Interest: The authors declare no conflict of interest.

\section{Abbreviations}

$0-\mathrm{SPC}$

A

ACE

$\mathrm{ACN}$

B

BIOPEP-UWM

Bis-Tris

B-SPC

C

DPP III

DPP IV

F

F-SPC

HMGR

HPLC

MLR

MPC

P

P-SPC

PK
Soybean protein concentrate before hydrolysis

Depending on the context: one-letter symbol alanine (amino acid) or A-type

fragment (daughter) ion according to Roepstorff and Fohlman [25]

Angiotensin-converting enzyme (EC 3.4.15.1)

Acetonitrile

Depending on the context: bromelain (EC 3.4.22.32) or B-type fragment (daughter) ion according to Roepstorff and Fohlman [25]

Depending on the context: database of bioactive peptide sequences [12] or database of sensory peptides and amino acids [20]

2,2-bis(hydroxymethyl)-2,2',2"'-nitrilotriethanol

Soybean protein concentrate hydrolyzed by bromelain

Depending on the context: parameter to compare susceptibility of proteins to proteolytic enzymes on the basis of chromatograms (calculated using Equation (1)) or C-type fragment (daughter) ion according to Roepstorff and Fohlman [25]

Dipeptidyl peptidase III (EC 3.4.14.4)

Dipeptidyl peptidase IV (EC 3.4.14.5)

Depending on the context: ficin (EC 3.4.22.3) or one-letter symbol of amino acid phenylalanine in peptide sequences

Soybean protein concentrate hydrolyzed by ficin

3-hydroxy-3-methylglutaryl-coenzyme A reductase (HMG-CoA reductase)

(EC 1.1.1.34)

High performance liquid chromatography

Multivariate linear stepwise regression

Milk protein concentrate

Depending on the context: papain (EC 3.4.22.2) or one-letter symbol of amino acid proline in peptide sequences

Soybean protein concentrate hydrolyzed by papain

Depending on the context: proteinase K (EC 3.4.21.64) or dipeptide prolyl-lysine annotated using one-letter code 
PK-SPC

Q-value

RP-HPLC

RP-HPLC-MS/MS

S

SPC

SSRCalc

TFA

$t_{R}$

UWM

Y
Soybean protein concentrate hydrolyzed by proteinase $\mathrm{K}$

Average free energy for the transfer of the amino acid chains from ethanol to water [65]

Reversed-phase high performance liquid chromatography

Reversed-phase high performance liquid chromatography online with tandem mass spectrometry

Depending on the context: symbol of relative area of peaks in defined data interval (in Equation (1)) or one-letter symbol of amino acid serine in peptide sequences Soybean protein concentrate

Sequence-Specific Retention Calculator

Trifluoroacetic acid

Retention time (e.g., in Equation (2))

University of Warmia and Mazury in Olsztyn

Depending on the context: one-letter symbol of amino acid tyrosine in peptide sequences or Y-type fragment (daughter) ion according to Roepstorff and Fohlman [25]

\section{Appendix A}

Table A1. Parent peptides released in silico from soybean proteins containing bitter-tasting peptides with and without the indicator status (bold and normal font, respectively).

\begin{tabular}{llll}
\hline \multicolumn{4}{c}{ Parent peptides released from profilin due to the simulated action of: } \\
\hline \multicolumn{1}{c}{$\mathrm{B}^{1}$} & \multicolumn{1}{c}{ F } & \multicolumn{1}{c}{ PK } \\
\hline VDDHLLCDIEG/VD, LL, EG & CDIEG/EG & VDDH/VD & EGNHL/EG \\
IIG/II, IG & IIG/II, IG & LLCDIE/LL & QGEP/GE \\
QSTDFPQFK/FP & QSTDFPQFK/FP & QSTDFPFK/FP & RGKKGP/RG, GP \\
PEEITA/EI & PEEITA/EI & MVIQG/VI & DQGY/GY \\
MVIQG/VI & ERPG/RP, RPG & LIIG/II, IG, LI & \\
VIRG/VI, RG & & QCNMVVE/VE & \\
LIIG/II, IG & & LIDQG/LI & \\
QCNMVVERPG/RP, RPG, VE & & & \\
LIDQG/LI & & & \\
\end{tabular}

\begin{tabular}{|c|c|c|c|}
\hline \multicolumn{4}{|c|}{ Parent peptides released from globulin $7 \mathrm{~S}$ due to the simulated action of: } \\
\hline $\mathrm{B}$ & $\mathrm{F}$ & $\mathrm{P}$ & PK \\
\hline PINLVVLPVQNDG/VL, LV & PFCHSTQCSRA/PF & PINLVVLPVQNDG/VL, LV & QNDGSTGL/GL \\
\hline RTPLMQVPVLVDLNG/VL, VD, LV, & SRPG/RP, RPG & TPLMQVPVLVDLNG/VL, & AASRP/RP \\
\hline DL & PQFL/FL & VD, LV, DL & GCHKNTCGL/GL \\
\hline PFCHSTQCSRA/PF & PSFL/FL & DVLA/VL & TQQTGL/GL \\
\hline SRPG/RP, RPG & SHFG/FG & STQQLG/LG & GEDV/GE \\
\hline EDVLA/VL & IIFG/FG, IF, II & PLVTVPQFLFSCA/FL, LF, & QKGL/GL \\
\hline STQQLG/LG & QDIFHDL/IF, DL & LV & RNTQGV/GV \\
\hline PLVTVPQFLFSCA/FL, LF, LV & ISSTIV/IV & PSFLVQK/FL, LV & GDAP/DA \\
\hline PSFLVQK/FL, LV & MQPRA/PR & IIFG/FG, IF, II & QGEY/GE, EY \\
\hline LPRNTQG/PR & EITL/EI & QFQNQDIFH/IF & SGEDL/GE, DL \\
\hline SHFG/FG & & SVFPLNK/FP, VF & RAEI/EI \\
\hline IIFG/FG, IF, II & & ISSTIVG/IV & EENL/EEN \\
\hline PNNMRQFQNQDIFHDLA/IF, DL & & MVLQQSVY/VY, VL & HSHGV/GV \\
\hline NVRVNSIRINQHSVFPLNK/FP, VF & & FTQVFA/VF & KCADL/AD, DL \\
\hline ISSTIVG/IV & & QQLPK/PK & \\
\hline TMISTSTPHMVLQQSVY/VY, VL & & PSVDLVMDK/VD, LV, DL & \\
\hline FTQVFA/VF & & DLMVQA/DL & \\
\hline QQLPK/PK & & VTCLG/LG & \\
\hline PSVDLVMDK/VD, LV, DL & & MQPR/PR & \\
\hline EDLMVQA/DL & & ITLG/LG & \\
\hline VTCLG/LG & & NLVVFDLA/VF, LV, DL & \\
\hline MQPRA/PR & & DLFNFA/LF, DL & \\
\hline \multicolumn{4}{|l|}{ EITLG/LG, EI } \\
\hline \multirow{2}{*}{\multicolumn{4}{|c|}{$\begin{array}{l}\text { RQLEENLVVFDLA/VF, LE, LV, DL, } \\
\text { EEN }\end{array}$}} \\
\hline & & & \\
\hline DLFNFA/LF, DL & & & \\
\hline
\end{tabular}


Table A1. Cont.

\begin{tabular}{|c|c|c|c|}
\hline \multicolumn{4}{|c|}{ Parent peptides released from $\beta$-conglycinin ( $\alpha$-chain) due to the simulated action of: } \\
\hline B & $\mathrm{F}$ & $\mathrm{P}$ & PK \\
\hline EECEEG/EG & EECEEG/EG & PIPFPR/PR, FP, PF, PFP, PIP & EKEECEEGEI/GE, EG, EI \\
\hline EIPRPRPRPQHPEREPQQPG/RP, RP, & EIPRPRPRPQHPER & PQPR/PR & GEKEEDEDEQP/GE \\
\hline RP, PR, PR, PR, EI & EPQQPG/RP, RP, RP, PR, & QFPFPR/PR, FP, FP, FPF, PF, & RKEEKRGEKGSEEED \\
\hline EEDEDEQPRPIPFPRPQ & PR, PR, EI & PFP & EDEDEEQDERQF/RG, \\
\hline PRQEEEHEQREEQEWPRK/RP, RP, & EEDEDEQPRPIPFPR & NPFLFG/FG, FL, LF, PF & GE \\
\hline PR, PR, PR, PR, FP, PF, PFP, PIP & PQPRQEEEHEQR & TLFK/LF & HQKEERNEEEDEDEE \\
\hline SEEEDEDEDEEQDE & EEQEWPRK/RP, RP, PR, & VLQR/VL & QQRESEESEDSEL/EL \\
\hline RQFPFPRPPHQK/PP, RP, PR, FP, FP, & PR, PR, PR, FP, PF, PFP, & PNTLLLPNH/LL, LL, LLL & RRHKNKNP/RR \\
\hline FPF, PF, PFP & PIP & LIVILNG/VI, IV, LI, IL & GSNRF/RF \\
\hline EERNEEEDEDEEQQRE & SEEEDEDEDEEQ & ILSLVNNDDR/LV, IL & NSKP/KP \\
\hline SEESEDSELRRHK/RR, EL & DERQFPFPRPPHQK/PP, & VVNPDNNE/VV & NHADADY/AD, AD, \\
\hline NPFLFG/FG, FL, LF, PF & RP, PR, FP, FP, FPF, PF, & LITLA/LI & DA \\
\hline SNRFETLFK/RF, LF & PFP & SFFLSSTE/FF, FL & QSGDAL/DA \\
\hline RIRVLQRFNQRSPQLQNLRDY/RF, & EEEDEDEEQQR & NILE/LE, IL & DTKF/KF \\
\hline & ESEESEDSEL/EL & VLFSR/LF, VL & SREEGQQQGEQRL/GE, \\
\hline RILEFNSK/LE, IL, EF & RRHK/RR & SVIVE/VI, VE, IV & EG \\
\hline PNTLLLPNHA/LL, LL, LLL & RFETL/RF & PFNLR/PF & SSEDKP/KP \\
\hline LIVILNG/VI, IV, LI, IL & QRFN/RF & DLDIFLSIVDMNE/FL, IF, & NEGAL/EG \\
\hline ILSLVNNDDRDSY/LV, IL & RFESFFL/FF, RF, FL & IV, VD, LD, DL & NEGDANI/DA, EG \\
\hline VVNPDNNENLRLITLA/LI, VV & FEEIN/EI & LLLPH/LL, LL, LLL & RAEL/EL \\
\hline RFESFFLSSTEA/FF, RF, FL & FSREEG/EG & IVILVINE/VI, VI, IV, LV, IL & DAQP/DA \\
\hline FSRNILEA/LE, IL & EISK/EI & QPLE/LE & KKKEEGNKGRKGP/GR, \\
\hline FEEINK/EI & FFEITPEK/FF, EI & QDIFVIPA/FV, IF, VI & GP, EG \\
\hline VLFSREEG/LF, VL, EG & DIFL/FL, IF & PVVVNA/VVV, VV, VV & \\
\hline EQRLQESVIVEISK/VI, VE, IV, EI & SEQDIFV/FV, IF & TSNLNFFA/FF & \\
\hline PFNLRSRDPIY/PF & SSIL/IL & NFLA/FL & \\
\hline FFEITPEK/FF, EI & & SQDNVISQIPSQVQE/VI & \\
\hline NPQLRDLDIFLSIVDMNEG/FL, IF, & & FVDA/FV, VD, DA & \\
\hline IV, VD, LD, DL, EG & & PLSSILR/IL & \\
\hline LLLPHFNSK/LL, LL, LLL & & & \\
\hline IVILVINEG/VI, VI, IV, LV, IL, EG & & & \\
\hline NIELVG/LV, EL, VG & & & \\
\hline EQQQEQQQEEQPLEVRK/LE & & & \\
\hline ELSEQDIFVIPA/FV, IF, VI, EL & & & \\
\hline PVVVNA/VVV, VV, VV & & & \\
\hline TSNLNFFA/FF & & & \\
\hline ENNQRNFLA/FL & & & \\
\hline SQDNVISQIPSQVQELA/VI, EL & & & \\
\hline FVDA/FV, VD, DA & & & \\
\hline PLSSILRA/IL & & & \\
\hline
\end{tabular}

${ }^{1}$ B, bromelain; F, ficin; P, papain; PK, proteinase $\mathrm{K}$.

\section{References}

1. Chatterjee, C.; Gleddie, S.; Xiao, C.W. Soybean bioactive peptides and their functional properties. Nutrients 2018, 10, 1211. [CrossRef] [PubMed]

2. Rizzo, G.; Baroni, L. Soy, soy foods and their role in vegetarian diets. Nutrients 2018, 10, 43. [CrossRef] [PubMed]

3. Chakrabarti, S.; Guha, S.; Majumder, K. Food-derived bioactive peptides in human health: Challenges and opportunities. Nutrients 2018, 10, 1738. [CrossRef] [PubMed]

4. Ding, Y.; Li, X.; Kan, J. Isolation and identification of flavor peptides from douchi (traditional Chinese soybean food). Int. J. Food Prop. 2017, 20, 1982-1994. [CrossRef]

5. Iwaniak, A.; Darewicz, M.; Mogut, D.; Minkiewicz, P. Elucidation of the role of in silico methodologies in approaches to studying bioactive peptides derived from foods. J. Funct. Foods 2019, 61, 103486. [CrossRef]

6. Lyndqvist, M. Flavour Improvement of Water Solutions Comprising Bitter Amino Acids. Master's Thesis, Swedish University of Agricultural Sciences, Department of Food Science, Uppsala, Sweden, 2010; Publication No. 277.

7. Zamyatnin, A.A. Fragmentomics of natural peptide structures. Biochemistry (Moscow) 2009, 74, 1575-1585. [CrossRef]

8. Liu, Z.P.; Wu, L.Y.; Wang, Y.; Zhang, X.S.; Chen, L. Bridging protein local structures and protein functions. Amino Acids 2008, 35, 627-650. [CrossRef] 
9. Iwaniak, A.; Minkiewicz, P.; Hrynkiewicz, M.; Bucholska, J.; Darewicz, M. Hybrid approach in the analysis of bovine milk protein hydrolysates as a source of peptides containing di- and tripeptide bitterness indicators. Pol. J. Food Nutr. Sci. 2020, 70, 139-150. [CrossRef]

10. Ashaolu, T.J. Application of soy protein hydrolysates in the emerging functional foods: A review. Int. J. Food Sci. Technol. 2019, 55, 421-428. [CrossRef]

11. The UniProt Consortium. UniProt: A worldwide hub of protein knowledge. Nucl. Acids Res. 2019, 47, D506-D515. [CrossRef]

12. Minkiewicz, P.; Iwaniak, A.; Darewicz, M. BIOPEP-UWM database of bioactive peptides: Current opportunities. Int. J. Mol. Sci. 2019, 20, 5978. [CrossRef] [PubMed]

13. Iwaniak, A.; Hrynkiewicz, M.; Bucholska, J.; Minkiewicz, P.; Darewicz, M. Understanding the nature of bitter-taste di- and tripeptides derived from food proteins based on chemometric analysis. J. Food Biochem. 2019, 43, e12500. [CrossRef] [PubMed]

14. Otagiri, K.; Miyake, I.; Ishibashi, N.; Fukui, H.; Kanehisa, H.; Okai, H. Studies of bitter peptides from casein hydrolyzate. II. Syntheses of bitter peptide fragments and analogs of BPIa (Arg-Gly-Pro-Pro-Phe-Ile-Val) from casein hydrolysate. Bull. Chem. Soc. Jpn. 1983, 56, 1116-1119. [CrossRef]

15. Peñta-Ramos, E.A.; Xiong, Y.L. Antioxidant activity of soy protein hydrolysates in a liposomal system. J. Food Sci. 2002, 67, 2952-2956. [CrossRef]

16. Lee, J. Soy Protein Hydrolysate: Solubility, Thermal Stability, Bioactivity, and Sensory Acceptability in a Tea Beverage. Master's Thesis, University of Minnesota, Minneapolis, MN, USA, 2011; pp. 1-137.

17. Moruz, L.; Käll, L. Peptide retention time prediction. Mass Spectrom. Rev. 2017, 36, 615-623. [CrossRef] [PubMed]

18. Spicer, V.; Yamchuk, A.; Cortens, J.; Sousa, S.; Ens, W.; Standing, K.G.; Wilkins, J.A.; Krokhin, O.V. Sequence-specific retention calculator. A family of peptide retention time prediction algorithms in reversed-phase HPLC: Applicability to various chromatographic conditions and columns. Anal. Chem. 2007, 79, 8762-8768. [CrossRef]

19. Darewicz, M.; Borawska, J.; Vegarud, G.E.; Minkiewicz, P.; Iwaniak, A. Angiotensin I-converting enzyme (ACE) inhibitory activity and ACE inhibitory peptides of salmon (Salmo salar) protein hydrolysates obtained by human and porcine gastrointestinal enzymes. Int. J. Mol. Sci. 2014, 15, 14077-14101. [CrossRef]

20. Iwaniak, A.; Minkiewicz, P.; Darewicz, M.; Sieniawski, K.; Starowicz, P. BIOPEP database of sensory peptides and amino acids. Food Res. Int. 2016, 85, 155-161. [CrossRef]

21. Visser, S.; Slangen, C.J.; Rollema, H.S. Phenotyping of bovine milk poteins by reversed-phase high-performance liquid chromatography. J. Chromatogr. A 1991, 548, 361-370. [CrossRef]

22. Bucholska, J.; Minkiewicz, P. The use of peptide markers of carp and herring allergens as an example of detection of sequenced and non-sequenced proteins. Food Technol. Biotechnol. 2016, 54, 266-274. [CrossRef]

23. Monaci, L.; Losito, I.; Palmisano, F.; Visconti, A. Reliable detection of milk allergens in food using a high-resolution, stand-alone mass spectrometer. J. AOAC Int. 2011, 94, 1034-1042. [CrossRef] [PubMed]

24. Paizs, B.; Suhai, S. Fragmentation pathways of protonated peptides. Mass Spectrom. Rev. 2005, 24, 508-548. [CrossRef] [PubMed]

25. Roepstorff, P.; Fohlman, J. Proposal for a common nomenclature for sequence ions in mass spectra of peptides. Biomed. Mass Spectrom. 1984, 11, 601. [CrossRef] [PubMed]

26. Kunda, P.B.; Benavente, F.; Catalá-Clariana, S.; Giménez, E.; Barbosa, J.; Sanz-Nebot, V. Identification of bioactive petides in a functional yogurt by liquid chromatography time-of-flight mass spectrometry assisted by retention time prediction. J. Chromatogr. A 2012, 1229, 121-128. [CrossRef]

27. Murray, N.M.; O’Riordan, D.; Jacquier, J.-C.; O’Sullivan, M.; Holton, A.; Wyne, K.; Robinson, R.C.; Barile, D.; Nielsen, S.D.; Dallas, D.C. Peptidomic screening of bitter and nonbitter casein hydrolysate fractions for insulinogenic peptides. J. Dairy Sci. 2018, 101, 2826-2837. [CrossRef]

28. Fan, J.; Saito, M.; Tatsumi, E.; Li, L. Preparation of angiotensin I-converting enzyme inhibiting peptides from soybean protein by enzymatic hydrolysis. Food Sci. Technol. Res. 2003, 9, 254-256. [CrossRef]

29. Iwaniak, A.; Minkiewicz, P.; Darewicz, M.; Hrynkiewicz, M. Food protein-originating peptides as tastants-Physiological, technological, sensory, and bioinformatic approaches. Food Res. Int. 2016, 89, $27-38$. [CrossRef] 
30. Matsui, T.; Zhu, X.L.; Shiraishi, K.; Ueki, T.; Noda, Y.; Matsumoto, K. Antihypertensive effect of salt-free soy sauce, a new fermented seasoning, in spontaneously hypertensive rats. J. Food Sci. 2010, 75, H129-H134. [CrossRef]

31. Wang, W.; Dia, V.P.; Vasconez, M.; de Mejia, E.G.; Nelson, R.L. Analysis of soybean protein-derived peptides and the effect of cultivar, environmental conditions, and processing on lunasin concentration in soybean and soy products. J. AOAC Int. 2008, 91, 936-994. [CrossRef]

32. Zhong, F.; Liu, J.; Ma, J.; Shoemaker, C.F. Preparation of hypocholesterol peptides from soy protein and their hypocholesterolemic effect in mice. Food Res. Int. 2007, 40, 661-667. [CrossRef]

33. De Mejia, E.G.; de Lumen, B.O. Soybean bioactive peptides: A new horizon in preventing chronic diseases. Sex. Reprod. Menop. 2006, 4, 91-95. [CrossRef]

34. Iwaniak, A.; Minkiewicz, P.; Darewicz, M. Food-originating ACE inhibitors, including antihypertensive peptides, as preventive food components in blood pressure reduction. Comp. Rev. Food Sci. Food Saf. 2014, 13, 114-134. [CrossRef]

35. Liu, R.; Cheng, J.; Wu, H. Discovery of food-derived dipeptidyl peptidase IV inhibitory peptides: A review. Int. J. Mol. Sci. 2019, 20, 463. [CrossRef] [PubMed]

36. Khaket, T.P.; Redhu, D.; Dhanda, S.; Singh, J. In Silico evaluation of potential DPP-III inhibitor precursors from dietary proteins. Int. J. Food Prop. 2015, 18, 499-507. [CrossRef]

37. Tu, M.; Cheng, S.; Lu, W.; Du, M. Advancement and prospects of bioinformatics analysis for studying bioactive peptides from food-derived protein: Sequence, structure, and functions. TrAC Trends Analyt. Chem. 2018, 105, 7-17. [CrossRef]

38. Udenigwe, C.C. Bioinformatic approaches, prospects and challenges of food bioactive peptide research. Trends Food Sci. Technol. 2014, 36, 137-143. [CrossRef]

39. Fu, Y.; Wu, W.; Zhu, M.; Xiao, Z. In silico assessment of the potential of patatin as a precursor of bioactive peptides. J. Food Biochem. 2016, 40, 366-370. [CrossRef]

40. Agyei, D.; Bambarandage, E.; Udenigwe, C. The role of bioinformatics in the discovery of bioactive peptides. In Encyclopedia of Food Chemistry, 2nd ed.; Melton, L., Shahidi, F., Varelis, P., Eds.; Elsevier Inc.: Cambridge, MA, USA, 2018; Volume 2, pp. 337-344. [CrossRef]

41. Sutopo, C.C.Y.; Sutrisno, A.; Wang, L.-F.; Hsu, J.-L. Identification of a potent angiotensin-I converting enzyme inhibitory peptide from black cumin seed hydrolysate using orthogonal bioassay-guided fractionations coupled with in silico screening. Process Biochem. 2020, in press. [CrossRef]

42. Alcaide-Hidalgo, J.M.; Romero, M.; Duarte, J.; López-Huertas, E. Antihypertensive effects of virgin olive oil (unfiltered) low molecular weight peptides with ACE inhibitory activity in spontaneously hypertensive rats. Nutrients 2020, 12, 271. [CrossRef]

43. Kinariwala, D.; Panchal, G.; Sakure, A.; Hati, S. Exploring the potentiality of Lactobacillus cultures on the production of milk-derived bioactive peptides with antidiabetic activity. Int. J. Pept. Res. Ther. 2020. [CrossRef]

44. Orts, A.; Revilla, E.; Rodriguez-Morgado, B.; Castaño, A.; Tejada, M.; Parrado, J.; Garciá-Quintanilla, A. Protease technology for obtaining a soy pulp extract enriched in bioactive compounds: Isoflavones and peptides. Heliyon 2018, 5, e01958. [CrossRef] [PubMed]

45. Garcia-Vaquero, M.; Mora, L.; Hayes, M. In vitro and in silico approaches to generating and identifying angiotensin-converting enzyme I inhibitory peptides from green macroalga ulva lactuca. Mar. Drugs 2019, 17, 204. [CrossRef] [PubMed]

46. Ashaolu, T.J. Health applications of soy protein hydrolysates. Int. J. Pept. Res. Ther. 2020. [CrossRef]

47. Darewicz, M.; Borawska-Dziadkiewicz, J.; Pliszka, M. Carp proteins as a source of bioactive peptides-An in silico approach. Czech J. Food Sci. 2016, 34, 111-117. [CrossRef]

48. Kęska, P.; Stadnik, J. Taste-active peptides and amino acids of pork meat as components of dry-cured meat products: An in-silico study. J. Sens. Stud. 2017, 32, e12301. [CrossRef]

49. Sun, X.D. Enzymatic hydrolysis of soy proteins and the hydrolysates utilisation. Int. J. Food Sci. Technol. 2011, 46, 2447-2459. [CrossRef]

50. Hrynkiewicz, M.; Iwaniak, A.; Bucholska, J.; Minkiewicz, P.; Darewicz, M. Structure-activity prediction of ACE inhibitory/bitter dipeptides-A chemometric approach based on stepwise regression. Molecules 2019, 24, 950. [CrossRef] 
51. Chanput, W.; Nakai, S.; Theerakulkait, C. Introduction of a new computer softwares for classification and prediction purposes of bioactive peptides: Case study in antioxidative peptides. Int. J. Food Prop. 2010, 13, 947-959. [CrossRef]

52. Wu, J.; Aluko, R.E. Quantitative structure-activity relationship study of bitter di- and tri-peptides including relationship with angiotensin I-converting enzyme inhibitory activity. J. Pept. Sci. 2007, 13, 63-69. [CrossRef]

53. Iwaniak, A.; Dziuba, J. BIOPEP-PBIL tool in the analysis of the structure of biologically active motifs derived from food proteins. Food Technol. Biotechnol. 2011, 49, 118-127.

54. Iwaniak, A.; Dziuba, J. Animal and plant origin proteins as the precursors of peptides with ACE inhibitory activity. Proteins evaluation by means of in silico methods. Food Technol. Biotechnol. 2009, 47, 441-449.

55. Arboleda, J.C.; Rojas, O.J.; Lucia, L.A. Acid-generated soy protein hydrolysates and their interfacial behavior on model surfaces. Biomacromolecules 2014, 15, 4336-4342. [CrossRef] [PubMed]

56. Mallick, P.; Schirle, M.; Chen, S.S.; Flory, M.R.; Martin, D.; Ranish, J.; Raught, B.; Schmitt, R.; Werner, T.; Kustr, B.; et al. Computational prediction of proteotypic peptides for quantitative proteomics. Nat. Biotechnol. 2007, 25, 125-131. [CrossRef] [PubMed]

57. Iwaniak, A.; Hrynkiewicz, M.; Bucholska, J.; Darewicz, M.; Minkiewicz, P. Structural characteristics of food protein-originating di- and tripeptides using principal component analysis. Eur. Food Res. Technol. 2018, 244, 1751-1758. [CrossRef]

58. Panjaitan, F.C.A.; Gomez, H.L.R.; Chang, Y.-W. In silico analysis of bioactive peptides released from giant grouper (Epinephelus lanceolatus) roe proteins identified by proteomics approach. Molecules 2018, 23, 2910. [CrossRef]

59. Vermeirssen, V.; van der Bent, A.; Van Camp, J.; van Amerongen, A.; Verstraete, W. A quantitative in silico analysis calculates angiotensin I converting enzyme (ACE) inhibitory activity in pea and whey protein digests. Biochimie 2004, 86, 231-239. [CrossRef]

60. Pokora, M.; Zambrowicz, A.; Zabłocka, A.; Dabrowska, A.; Szołtysik, M.; Babij, K.; Eckert, E.; Trziszka, T.; Chrzanowska, J. The use of serine protease from Yarrowia lipolytica yeasts in the production of biopeptides from denatured egg white proteins. Acta Biochim. Pol. 2017, 64, 245-253. [CrossRef]

61. Khaldi, N. Bioinformatic approaches for identifying new therapeutic bioactive peptides in food. Funct. Food Health Dis. 2012, 2, 325-338. [CrossRef]

62. Rawlings, N.D. A large nad accurate collection of peptidase cleavages in the MEROPS database. Database (Oxford) 2009, 2009, bap015. [CrossRef]

63. Worsztynowicz, P.; Białas, W.; Grajek, W. Integrated approach for obtaining bioactive peptides from whey proteins hydrolysed using a new proteolytic lactic acid bacteria. Food Chem. 2020, 312, 126035. [CrossRef]

64. Li, X.; Xie, X.; Wang, J.; Xu, Y.; Yi, S.; Zhu, W. Identification, taste characteristics and molecular docking study of novel umami peptides derived from the aqueous extract of the clam Meretrix meretrix Linnaeus. Food Chem. 2020, 312, 126053. [CrossRef] [PubMed]

65. Ney, K. Voraussage der Bitterkeit von Peptiden aus deren Aminosäurezu-sammensetzung. Prediction of bitterness of peptides from their amino acid composition. Z. Lebensm. Unters. Forsch. 1971, 147, 64-68. [CrossRef]

66. Maehashi, K.; Huang, L. Bitter peptides and bitter taste receptors. Cell. Mol. Life Sci. 2009, 66, 1661-1671. [CrossRef] [PubMed]

67. Lemieux, L.; Simard, R.E. Bitter flavour in dairy products. II. A review of bitter peptides from caseins: Their formation, isolation and identification, structure masking and inhibition. Láit 1992, 72, 335-382. [CrossRef]

68. Wang, W.; Gonzalez de Mejia, E. A new frontier in soy bioactive peptides that may prevent age-related chronic diseases. Compr. Rev. Food Sci. Food Saf. 2005, 4, 63-78. [CrossRef]

69. Cheung, L.K.Y.; Aluko, R.E.; Cliff, M.A.; Li-Chan, E.C.Y. Effects of exopeptidase treatment on antihypertensive activity and taste attributes of enzymatic whey protein hydrolysates. J. Funct. Foods 2015, 13, 262-275. [CrossRef]

70. Gallego, M.; Mora, L.; Toldrá, F. The relevance of dipeptides and tripeptides in the bioactivity of dry-cured ham. Food Prod. Process. Nutr. 2019, 1, 2. [CrossRef]

71. FitzGerald, R.J.; Cermeño, M.; Khalesi, M.; Kleekayai, T.; Amigo-Benavent, M. Application of in silico approaches for the generation of milk protein-derived bioactive peptides. J. Funct. Foods 2020, 64, 103636. [CrossRef]

(C) 2020 by the authors. Licensee MDPI, Basel, Switzerland. This article is an open access article distributed under the terms and conditions of the Creative Commons Attribution (CC BY) license (http://creativecommons.org/licenses/by/4.0/). 